\title{
norden
}

\section{The European Union and the Arctic}

Main developments July 2008-July 2010 





\section{European Union and the Arctic}

Main developments July 2008-July 2010

Adele Airoldi

ANP 2010:763 


\section{European Union and the Arctic}

Main developments July 2008-July 2010

ANP 2010:763

(C) Nordic Council of Ministers, Copenhagen 2010

ISBN 978-92-893-2138-9

Print: Kailow Express ApS

Layout: PUB/ NMR

Photos: ImageSelect; Coverphote; Silje Bergum Kinsten: p. 12, p. 18, p. 26 and p. 58;

Mats Holmström: p. 44

Copies: 150

Printed on environmentally friendly paper

This publication can be ordered on www.norden.org/order. Other Nordic publications are available at www.norden.org/publications

Printed in Denmark

Nordic Council of Ministers

Ved Stranden 18

DK-1061 København K

Phone (+45) 33960200

Fax (+45) 33960202

\author{
Nordic Council \\ Ved Stranden 18 \\ DK-1061 København K \\ Phone (+45) 33960400 \\ Fax (+45) 33111870
}

www.norden.org

\section{Nordic co-operation}

Nordic cooperation is one of the world's most extensive forms of regional collaboration, involving Denmark, Finland, Iceland, Norway, Sweden, and three autonomous areas: the Faroe Islands, Greenland, and Åland.

Nordic cooperation has firm traditions in politics, the economy, and culture. It plays an important role in European and international collaboration, and aims at creating a strong Nordic community in a strong Europe.

Nordic cooperation seeks to safeguard Nordic and regional interests and principles in the global community. Common Nordic values help the region solidify its position as one of the world's most innovative and competitive. 


\section{Contents}

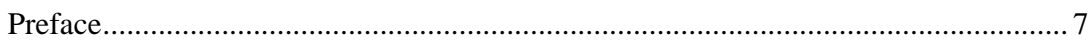

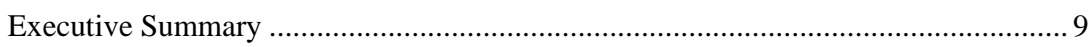

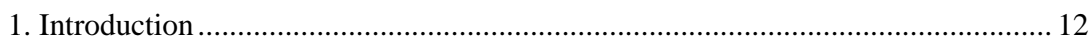

2. The EU approach to Arctic issues: the formulation process ................................. 19

3. EU action for the Arctic: main developments in the relevant policy sectors .......... 27

3.1 Protecting and preserving the Arctic......................................................... 28

3.1. 1. Climate change, including security issues .................................. 28

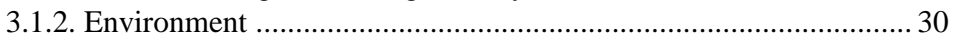

3.1.3 Research .......................................................................... 32

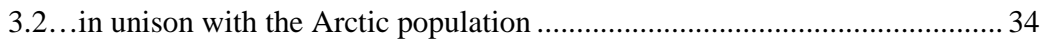

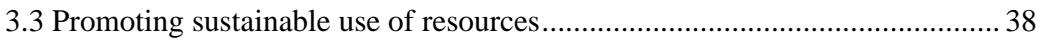

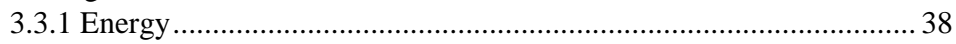

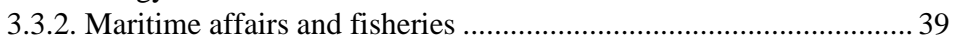

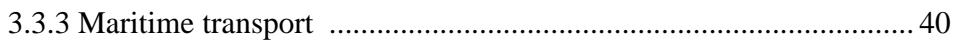

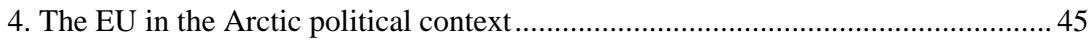

4.1. The Northern Dimension ........................................................................ 46

4.2 The multilateral framework......................................................................... 47

4.2.1 Barents Euro-Arctic cooperation .................................................. 47

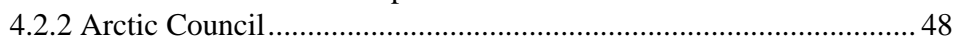

4.2.3. Nordic Council of Ministers.............................................................. 49

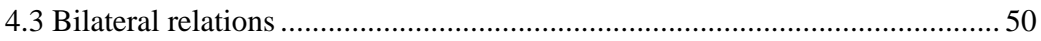

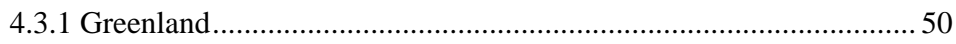

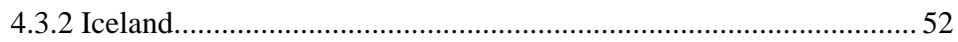

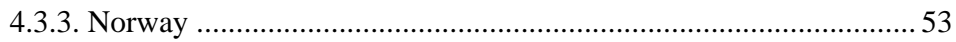

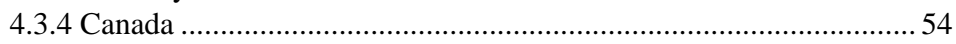

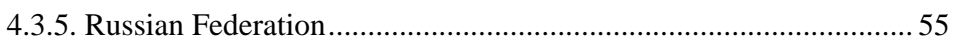

4.3.6. United States .......................................................................... 56

5. A long and winding road - elements for interim assessment................................ 59

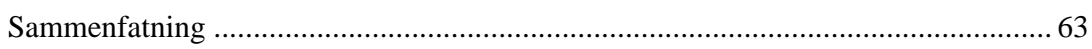





\section{Preface}

The interest for the Arctic region has been intense in recent years, as demonstrated by intensified political debate on Arctic issues and increased national activity and multilateral cooperation in the region.

The Nordic Council of Ministers has also been part of the debate on the Arctic demonstrated by the conferences "Common Concern for the Arctic" held in Ilulissat, Greenland, in September 2008 and "Arctic - Changing Realities” held in Copenhagen, Denmark, in May 2010. In October 2010 Nordic Council of Ministers will share ideas with the EU on potential concrete cooperation with regards to the sustainable development of the Arctic.

During the last couple of years the European Union has paid increased attention to the Arctic region, expressed through the Commission's Arctic Communication (November 2008) and the Council's Conclusions (December 2009). The Arctic now appears as a recognized feature in EU policies and activities.

This paper commissioned by the Nordic Council of Ministers, written by Ms. Adele Airoldi, describes and analyses the principal elements of the EU approach to Arctic issues as it has developed from July 2008 to July 2010, updating the NCM report "The European Union and the Arctic - policies and actions” from 2008. It reviews EU documents and pronouncements on Arctic issues, explores the development in the main EU policy sectors which impact the Arctic region and positions the EU in the wider Arctic political context through examining EU multilateral cooperation and bilateral relations. 
It also aims at giving an input to the ongoing co-operation of the Nordic Council of Ministers with the EU on Arctic questions.

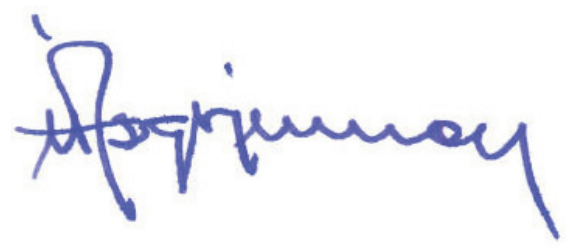

Halldór Ásgrímsson

Secretary General

Nordic Council of Ministers 


\section{Executive Summary}

A number of EU policies and activities, either because of their substance or of their territorial target, have an impact on the Arctic, as described in the 2008 report "The European Union and the Arctic - Policies and actions". This paper is an update of the report up to July 2010.

The European Commission communication "The European Union and the Arctic region" of November 2008 and the "Council conclusions on Arctic issues" of December 2009, which broadly endorse the communication with a keener attention to internal and external political implications, recognize the need for a more systematic and structured approach to Arctic issues, centred on three main objectives - preserving the Arctic in unison with its population, promoting sustainable use of resources, contributing to enhanced Arctic multilateral governance - and identify actions to be pursued in the relevant EU policy areas to implement those objectives. The analysis of these texts shows that the EU sees sustainability as the paramount criterion for its action in the Arctic. It also shows that the EU intends to contribute to the orderly development of common responses to the challenges in the region in close cooperation with Arctic states and other stakeholders within the existing cooperation frameworks. In this perspective, the idea of an Arctic Treaty, launched originally by the European Parliament in 2008, does not find support.

The policy sectors where Arctic-relevant activity has developed most - in the two-year period covered by the paper - continue to be research, environment and maritime affairs, particularly maritime transport. In these sectors, a number of Arctic-specific initiatives have been launched and participation in international activities has been stepped up. The Northern Dimension for its part is considering ways to revitalize the Arctic Window. Similarly, awareness of and attention to Arctic issues are increasing significantly in other relevant policy areas. The exception remains EU action in- 
spired by animal welfare preoccupations - notably the ban on seal products - which continues to be at odds with the vision of Arctic populations, particularly indigenous peoples, as well as impairing their economic interests. This highlights the need, which the EU has recognized, to promote further sustained two-way dialogue and exchange of information, to prevent new incidents of this sort taking place.

While a positive attitude by local populations is an important element for a successful EU involvement in the Arctic, the analysis of the broader political context appears to show that the road towards full acceptance of the EU as a player on the present complex Arctic political scene is still an uphill one. Nearly all Arctic states have produced national strategies where they have manifested clear views on how Arctic cooperation should develop with the Arctic Council as the central, privileged forum; some in particular are showing a marked reluctance to opening this forum to others. In this perspective, the challenge for the EU, at this stage, would be to further assert its presence by bringing its experience and political and economic weight, in a targeted and sustained manner, in support of the search for internationally agreed solutions to Arctic-wide problems - such as adaptation to climate change, air and maritime pollution, safety of maritime transport. At the same time, the internal effort to ensure greater consistency and better prioritization of EU policies and actions relevant for the Arctic should be pursued.

The progress report due by the Commission mid-2011 would be the occasion to assess whether and in which form a fully fledged EU Arctic policy is possible and desirable, and to point the way forward. 



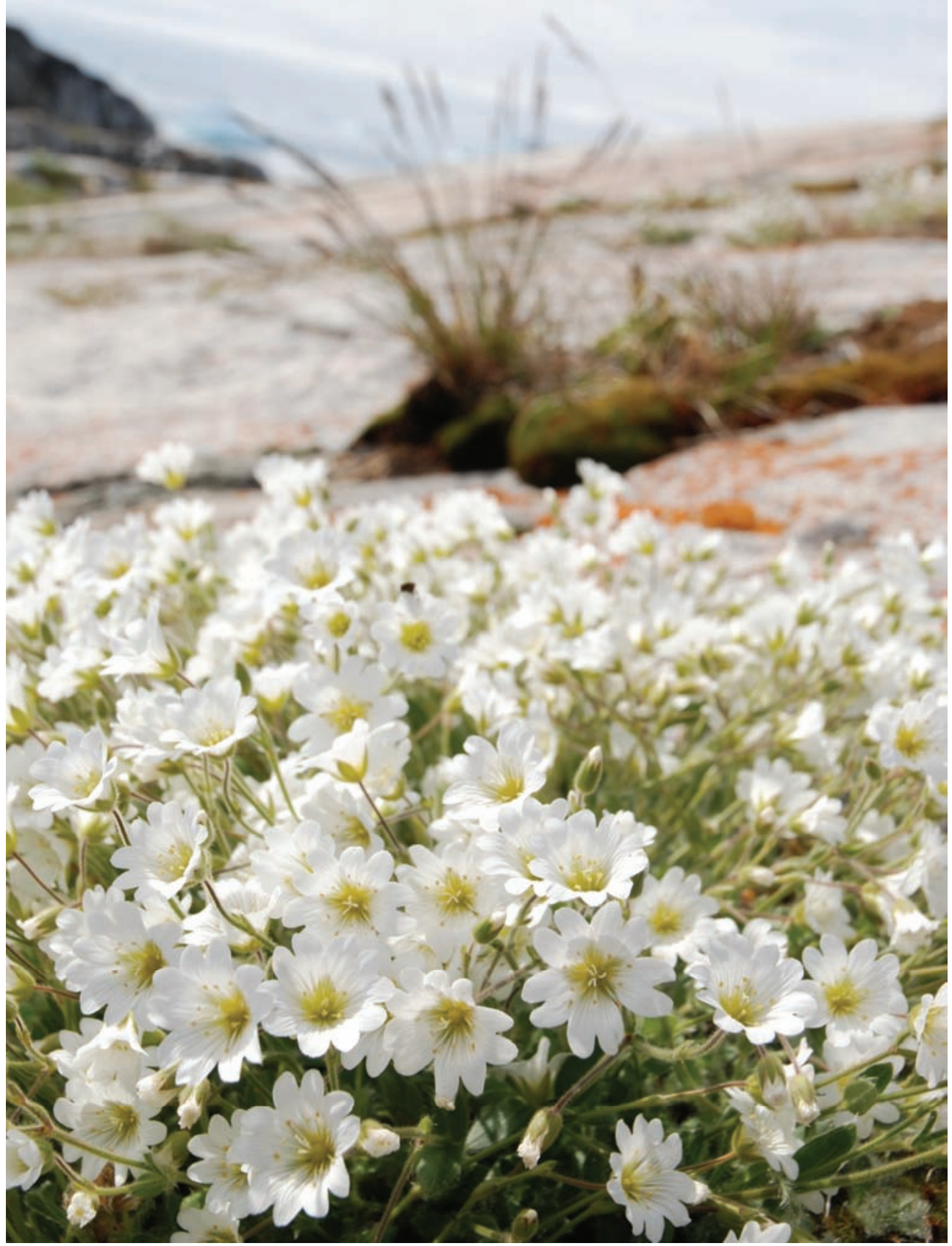




\section{Introduction}

This paper updates the report "The European Union and the Arctic - Policies

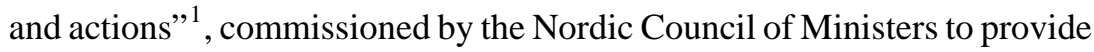
an overview of Arctic-relevant EU activities. The update covers the period from July 2008, when the report was issued, to July 2010.

This period has seen an unprecedented surge of interest for the Arctic region, both from near and far states, fuelling fears of a "scramble for the Arctic". It has seen the five circumpolar states reaffirming their sovereign rights and demonstratively exerting their stewardship in the Arctic Ocean, beyond border disputes. It has seen the Arctic states producing, one after the other, new assertive Arctic strategies. It has seen Arctic cooperation intensifying, and the debate on Arctic governance raging and then sobering down.

Against this background, spurred by and reacting to these developments, a conscious effort to develop a specific EU approach to Arctic issues has been undertaken, and is underway. The Arctic has become a recognized feature in EU policies and action.

The paper aims at describing and analysing the principal elements of the EU approach as it has developed over the last two years. Section 2 retraces its formulation by the EU institutions, Section 3 lists the main Arcticrelevant actions in different EU policy sectors, and Section 4 considers the $\mathrm{EU}$ in the Arctic political context. A general assessment, forcedly of an interim character, is set out in Section 5.

Several changes in the EU setup and functioning, important for understanding the developments related in the paper, took place in the period under consideration.

\footnotetext{
${ }^{1}$ http://www.norden.org/da/publikationer/publikationer/2008-729/at_download/ publicationfile
} 
First and foremost, on 1 December 2009, the Lisbon Treaty entered into force $^{2}$. The Lisbon Treaty reforms the institutions, their legal powers and their interplay. A summary of the present functioning of EU institutions, highlighting changes in respect of the situation described in the Appendix to the 2008 report, is given in the box below.

The Commission, presently headed by Mr. Barroso in his second mandate, remains as a general rule responsible for the submission of legislative proposals. It continues to ensure the management and implementation of EU policies and of the budget at EU level, and to oversee the application of EU law under the control of the EU Court of Justice. It also ensures as a rule the EU external representation, except for common foreign and security policy.

The European Council, the four-yearly meeting of Heads of State or Governments and of the president of the Commission, becomes an institution in its own right, without legislative functions but with the task of providing the necessary impetus for EU development and defining the general political directions and priorities, as a rule by consensus. It is headed by a new political figure, the President of the European Council - presently Mr. Van Rompuy.

The Council exercises legislative and budgetary functions, as a general rule jointly with the Parliament (see below) and by taking decisions by qualified majority. The Council continues to meet in different configurations, and is presided by a representative of the Member State which has the rotating Presidency, which is maintained. The Lisbon Treaty introduced an innovation by providing that the Foreign Affairs Council, which decides on the EU foreign policy as a rule by unanimity, be presided by the High Representative for Foreign affairs and Security Policy - a new office which combines the functions previously attributed to the High Representative/Secretary General of the Council with those of Vice-President of the Commission responsible for external relations. In this double capacity, the HR - presently Baroness Ashtonsteers and contributes to the EU foreign policy, ensures consistency of the EU's external action, represents the EU for matters relating to the common foreign and security policy, conducts political dialogue with third parties and expresses the EU position in international fora in matters under the HR's responsibility. The HR is assisted by the European External Action Service, in

${ }^{2}$ Cf. http://europa.eu/lisbon_treaty/glance/index_en.htm for overall information. The consolidated versions of the Treaty on European Union (TEU) - which sets out general provisions and basic principles as well main characteristics and powers of the EU institutions - and of the Treaty on the Functioning of the European Union (TFEU) - which organises the functioning of the EU and determines how the EU can act in the different policy fields - can be found at http://eur-lex.europa.eu/LexUriServ/LexUriServ.do?uri=OJ:C:2010:083:FULL:EN:PDF. When Treaty Articles are quoted in this paper, reference is made to the consolidated text. 
the process of being set up, composed of officials drawn from the staff of EU institutions and from national diplomatic services of the Member States. The Commission delegations in third countries become EU delegations, and cooperation with diplomatic services of Member States is intensified.

Possibly the most relevant change introduced by the Lisbon Treaty is the strengthened role of the European Parliament (present President Mr. Buzek), whose approval or consent are now needed for nearly all important appointments in the EU institutions as well as for the conclusion of most international agreements. The EP now decides, together with the Council, on the whole EU budget, and the multiannual financial framework. Co-decision with the Council, renamed "ordinary legislative procedure" is extended to the great majority of policy sectors, including agriculture and fisheries (except for prices and quotas), energy (except for measures of a fiscal nature), civil protection, tourism and structural funds.

In the same spirit of increasing democratic legitimacy of the EU legislative process, national parliaments acquire for the first time a role, in that they have the possibility to examine and object to proposed legislation. Furthermore, the Lisbon Treaty has introduced the so called "citizen initiative" (Article $11 \mathrm{TEU}$ ) which provides for the possibility for at least a million EU citizens from a significant number of Member States to invite the Commission to submit a proposal.

It is not completely clear yet how some of the new arrangements are going to work within the EU - such as the co-presence in the external EU representation of the newly created President of the European Council and High Representative with the President of the Commission and the representative of the rotating Presidency of the Council.

It is also far too early to assess how the changes introduced by the Lisbon Treaty will influence EU action, including with respect to Arctic issues. While it is a fact that the Parliament has increased powers in Arctic-relevant fields, innovations such as the "citizen initiative" may be a double-edged sword, vehicle of a public opinion easily swayed in one direction or another.

The composition and organization of the Parliament and of the Commission have also changed in the period under consideration. The Parliament, following the elections of June 2009, has a new membership and new politi- 
cal groupings have been established. ${ }^{3}$ A new Commission has been appointed in February $2010^{4}$, and its internal structure, namely the sharing of responsibilities between Commissioners and Directorate Generals (DG), has been modified as a consequence.

Beyond the new institutional interplay, the change in membership of Parliament and Commission may be of relevance insofar as the advance of nonmainstream issues, such as the Arctic, is often driven by the personal interest of individual members - and the political weight of the bearers of that interest.

${ }^{3}$ http://www.europarl.europa.eu/parliament/public/staticDisplay.do?id=146\&language=en

${ }^{4} \underline{\text { http://ec.europa.eu/index_en.htm }}$ 



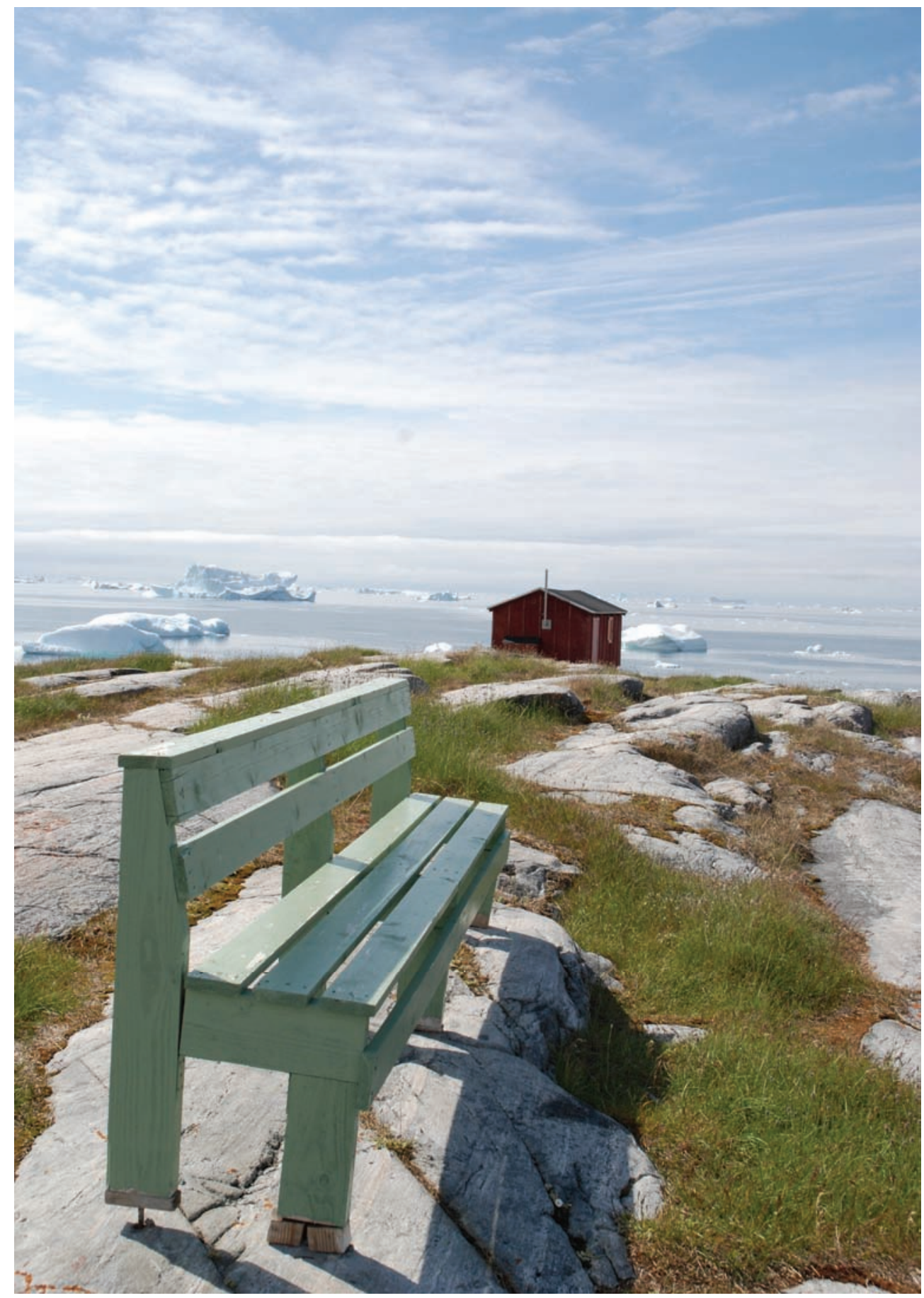




\section{The EU approach to Arctic issues: the formulation process}

This section analyses the documents and pronouncements which mark the beginning and further shaping of the EU approach to Arctic issues in the period under consideration. It does so in chronological sequence, in order better to show the institutional interplay.

In October 2008, the European Parliament, giving resonance to the growing interest for the Arctic both in the EU and the international context, adopted a resolution on Arctic governance ${ }^{5}$.

European Parliament resolutions are acts with no binding value, aiming at giving political impetus to the legislative or political process

The resolution set out the concerns of the Parliament for the environmental, geopolitical and social consequences of climate change in the Arctic, expressed the hope that the forthcoming Commission communication on the Arctic would "lay the foundations for a meaningful EU Arctic policy", and listed the essential elements it wished to be addressed in the communication:

“a) the state of play in relation to climate change, and adaptation to it, in the region;

b) policy options that respect the indigenous populations and their livelihoods;

c) the need to cooperate with our Arctic neighbours on cross-border issues, in particular maritime safety; and

\footnotetext{
${ }^{5}$ http://www.europarl.europa.eu/sides/getDoc.do?pubRef=-//EP//TEXT+TA+P6-TA-20080474+0+DOC $+\mathrm{XML}+\mathrm{V} 0 / / \mathrm{EN} \&$ language $=\mathrm{EN}$
} 
d) options for a future cross-border political or legal structure that could provide for the environmental protection and sustainable orderly development of the region or mediate political disagreement over resources and navigable waterways in the High North;”

The resolution ended with a controversial suggestion, widely quoted and often incorrectly interpreted as an expression of the political will of the EU as such:

\begin{abstract}
" that the Commission should be prepared to pursue the opening of international negotiations designed to lead to the adoption of an international treaty for the protection of the Arctic, having as its inspiration the Antarctic Treaty, as supplemented by the Madrid Protocol signed in 1991, but respecting the fundamental difference represented by the populated nature of the Arctic and the consequent rights and needs of the peoples and nations of the Arctic region; [ believes], however, that as a minimum starting-point such a treaty could at least cover the unpopulated and unclaimed area at the centre of the Arctic Ocean";
\end{abstract}

In November 2008, the Commission submitted to the European Parliament and the Council its much-awaited communication "The European Union and the Arctic region" ${ }^{\circ}$, prepared by an interservice working group under the lead of the DG on External Relations.

Commission communications are acts - not legally or otherwise binding where the Commission expresses its views on a given subject. They do typically contain or accompany suggestions for action by the EU or even legislative proposals. Communications can be equated to an opening bid by the Commission, which would require to be endorsed by the Council and the Parliament before it could be considered an expression of EU policy.

The Commission recalled the genesis of its reflection in the Integrated Maritime Policy and in the risks to security and stability brought by climate change in the Arctic and proceeded to set out EU interests and propose actions for EU Member States and institutions around three main policy objectives:

${ }^{6}$ COM (2008)763 http://eur-lex.europa.eu/LexUriServ/LexUriServ.do?uri= CELEX:DKEY=483680:EN:NOT 
“- Protecting and preserving the Arctic in unison with its population

- Promoting sustainable use of resources

- Contributing to enhanced Arctic multilateral governance”

For each of those objectives, the communication indicated more specific policy objectives in the relevant areas, accompanied by specific proposals for action. While the actions proposed under the first two objectives, although with different degrees of relevance, amplitude, concreteness and feasibility, capture to a large extent the Parliament's preoccupations, the Commission's position on governance is far less bold and innovative than that of the Parliament, and explicitly anchors proposed action to the implementation of existing obligations and the further development of a cooperative governance system with the UN Convention on the Law of the Sea (UNCLOS) at its centre.

The general conclusion is also coached in a rather cautious language, reflecting awareness that the EU has yet to establish its presence on the Arctic scene:

"The suggestions contained in this Communication aim to provide the basis for a
more detailed reflection. This will be useful for implementing the EU's strategic
initiatives, including the Integrated Maritime Policy. The present Communication
should also lead to a structured and coordinated approach to Arctic matters, as
the first layer of an Arctic policy for the European Union. This will open new
cooperation perspectives with the Arctic states, helping all of us to increase stabi-
lity and to establish the right balance between the priority goal of preserving the
Arctic environment and the need for sustainable use of resources” (underlining
added).

The General Affairs and External Relations Council in December 2008 came up with a first reaction soon after the presentation of the communication, with short conclusions of a general nature ${ }^{7}$. The Council welcomed the communication as a first layer of an EU Arctic policy, noted the special role of the Arctic EU Member States and Greenland, recognized the need to act in a systematic and coordinated manner to address the Arctic challenges and to enhance the EU contribution to Arctic multilateral cooperation, and asked for a more detailed reflection on the proposals contained in the communication.

\footnotetext{
${ }^{7}$ 16826/08 http://register.consilium.europa.eu/pdf/en/08/st16/st16826.en08.pdf
} 
In April 2009, the European Parliament discussed another motion for a resolution ${ }^{8}$ calling on the Council and the Commission to initiate international negotiations for a treaty for the protection of the Arctic, modeled on the Antarctic Treaty, and to work at a series of initiatives aiming at the sustainable development of the region. However, given serious objections by both the Council and the Commission representatives present in the discussion, who underlined the politically untimely and potentially counterproductive character of such call ${ }^{9}$, the Parliament voted to postpone consideration of the motion, which was subsequently withdrawn.

The detailed reflection on the Commission communication was undertaken mainly in the second half of 2009, under Swedish Presidency.

The results of this work ${ }^{10}$ were long and detailed Council conclusions on Arctic issues, adopted by the Foreign Affairs Council in December 2009. ${ }^{11}$

Council conclusions, while not a legally binding act, express the unanimous political agreement by all Member States on the matter examined, and do often form the basis for further consideration or action.

Council conclusions are as a rule adopted by consensus. This implies that each sentence is likely to have been weighed and fine-tuned in order to arrive at formulations which would accommodate the views of all Member States, in particular of those most interested in the subject matter. The text is therefore worth a close analysis.

The key sentence is possibly the initial one where the Council "welcomes the gradual formulation of a policy on Arctic issues to address EU interests and responsibilities, while recognising Member States' legitimate interests and rights in the Arctic".

\footnotetext{
${ }^{8}$ http://www.europarl.europa.eu/sides/getDoc.do?type=MOTION\&reference=P6-RC-20090163\&language $=\mathrm{EN}$

${ }^{9} \mathrm{http}: / /$ www.europarl.europa.eu/sides/getDoc.do?type=CRE\&reference= 20090401\&secondRef=ITEM-013\&language $=\mathrm{EN}$

${ }^{10}$ All the Council's working parties competent for the different policy fields treated in the communication were involved in the reflection. The contributions were centralized and coordinated by the Working Party on Eastern Europe and Central Asia (COEST), competent for Arctic matters via the "Russia connection".

${ }^{11} \mathrm{http} / / /$ www.consilium.europa.eu/uedocs/cms_data/docs/pressdata/EN/foraff/111814.pdf
} 
Several elements can be noted: the stress on the "gradual" character of the formulation, the passage from "Arctic policy", as used in previous occasions, to the less specific "policy on Arctic issues", the mention of EU responsibilities alongside that of its interests, and the recognition of Member States' - presumably Arctic Member States'- special position.

The Council then sets out the bases on which a (rather than the) EU policy on Arctic issues should be funded :

“ - Effective implementation by the international community of adequate measures to mitigate climate change that are required to preserve the unique characteristics of the Arctic region;

- Reinforced multilateral governance through strengthening and consistent implementation of relevant international, regional and bilateral agreements, frameworks and arrangements;

- The United Nations Convention on the Law of the Sea (UNCLOS) and other relevant international instruments;

- Formulating and implementing EU actions and policies that impact on the Arctic with respect for its unique characteristics, in particular the sensitivities of ecosystems and their biodiversity as well as the needs and rights of Arctic residents, including the indigenous peoples ;

- Maintaining the Arctic as an area of peace and stability and highlighting the need for responsible, sustainable and cautious action in view of new possibilities for transport, natural resource extraction and other entrepreneurial activities linked to melting sea ice and other climate change effects.”

Here again the stress is on EU responsibilities - as well as on the EU sense of responsibility in the pursuit of EU interests. There is also the preoccupation to make it perfectly clear the EU will to remain within and in line with the existing governance framework, particularly UNCLOS.

Even when approving the three main policy objectives proposed by the Commission the Council further qualifies the third one "Contributing to enhanced governance in the Arctic" with the somewhat repetitive but obviously politically important addition "through implementation of relevant agreements, frameworks and arrangements, and their further development".

Underlining that further work is needed, the conclusions continue with a long list of considerations and invitations to actions to undertake by priority, as necessary for the "next step towards the formulation of an overarching approach to EU policy on Arctic issues" a rather convoluted wording which seems to add an extra layer between the present situation and the possible ultimate result - EU policy. 
The actions listed inevitably reflect the composite, multidisciplinary nature of the subject, as well as the different priorities and wishes by Member States meeting in the Council. They will be referred to in more detail in Section 3 of this paper.

The Council concludes by inviting the Commission to present a progress report by June 2011.

The Parliament issued from the 2009 elections has maintained an active interest for the Arctic. In April 2010, it held a rather extensive debate on the EU policy on Arctic issues ${ }^{12}$, with the participation of the High Representative.

A report for a EU strategy in the High North is being prepared by Michael Gahler (PPE Group) for the autumn 2010. A EU-Arctic Forum has been initiated to provide MEPs with an open platform for learning about and debating Arctic issues; the European Parliament Intergroup on "Climate Change, Biodiversity and Sustainable Development" is in the process of establishing a sub-group with the Arctic as its main theme, intended to address all Arctic-relevant issues.

Furthermore, in September 2010, the Parliament hosts the bi-annual meeting of Arctic parliamentarians.

\footnotetext{
${ }^{12}$ http://www.europarl.europa.eu/sides/getDoc.do?type=CRE\&reference= 20100310\&secondRef=ITEM-011\&language $=$ EN
} 



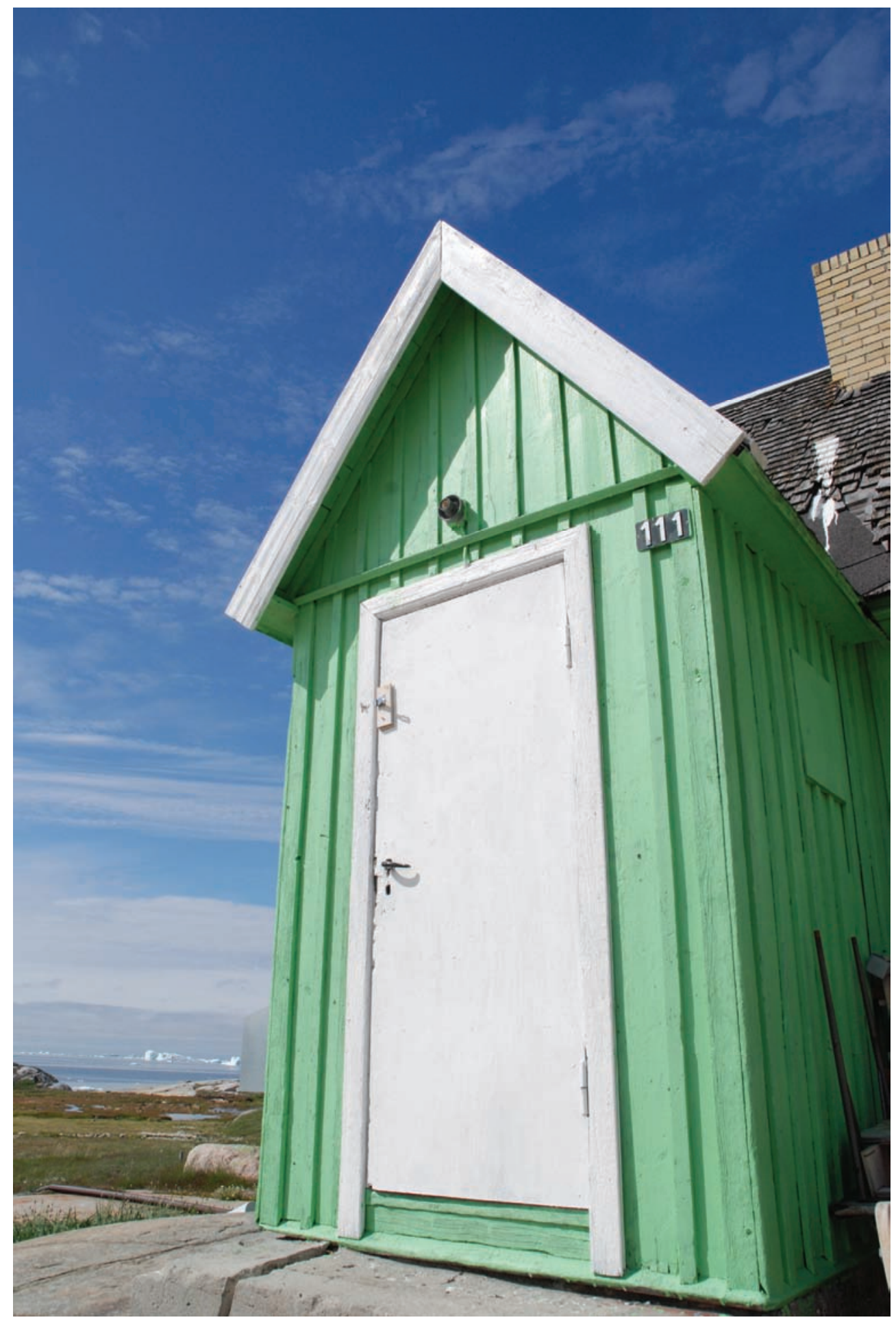




\section{EU action for the Arctic: main developments in the relevant policy sectors}

This section aims at giving a reasoned catalogue of the principal Arcticrelated developments in relevant EU policy sectors in the period under consideration. The developments are clustered around the main policy objectives for EU action as set out by the Commission and approved by the Council, it being understood that many policy sectors are to varying degrees interlinked, thus making the subdivisions used below to a certain extent artificial.

General information about the different EU policies can be found in the 2008 report - to which reference is made at each occasion. Furthermore, regular reference is made to the relevant parts of the Commission communication and of the Council conclusions - the two main texts guiding the development of EU action. Changes in the organizational structure of the Commission are also indicated. ${ }^{13}$

\footnotetext{
${ }^{13}$ The Directorate General competent for external relations (DG RELEX) maintains a leading function for the coordination of EU Arctic issues in the Commission, in close association with the DG competent for maritime affairs (DG MARE), and with the active contribution of an interservice group. The group, in which also the European Environment Agency takes part, meets regularly to provide expertise in all Arctic- relevant fields. The main EU/Arctic website is http://ec.europa.eu/maritimeaffairs/arctic_overview_en.html
} 


\subsection{Protecting and preserving the Arctic}

\subsection{Climate change, including security issues ${ }^{14}$}

The Lisbon Treaty identifies climate change as the main worldwide environmental problem (Art. 191 TFEU). Consistent with this, the new Commission has a Commissioner responsible for climate change only and correspondingly a dedicated Directorate General (DG CLIMA) ${ }^{15}$.

Climate change, as well as remaining the crucial driver of developments which have drawn attention to the Arctic, remains an issue which goes far beyond EU capacities. It is therefore understandable that both the Commission communication (section 2.1) and the Council conclusions (paragraph 1) address climate change in quite general language, focussing on international action, particularly on mitigation.

In December 2008, one year ahead of the UN COP 15 in Copenhagen, the European Council agreed the package of measures usually referred to as the "20-20-20-package": a unilateral decision to reduce greenhouse gas emissions by $20 \%$ relative to 1990 (to be raised to $30 \%$ in the framework of a satisfactory international agreement), and a commitment to increase the share of renewable energy from then approximately. 8,5 \% to $20 \%$, both targets to be achieved by 2020. It also agreed on the terms for the emissions trading scheme (ETS) for the period 2013-20. In addition to these binding commitments, adopted as legal texts in April 2009 , the EU has a nonbinding target, also for 2020, of improving energy efficiency by $20 \%$ compared to the "business as usual' scenario.

Since 2008, the economic recession has significantly changed the perspective of the agreed measures. Sharply falling $\mathrm{CO}_{2}$-emissions in 2008 and 2009 imply that overall EU emissions are already now around $15 \%$ below 1990 levels, enough to put the $20 \%$ reduction target within reach well ahead of 2020, particularly as the additional $5 \%$ is expected to be generated by mitigation projects in developing countries. This has caused the Commission to raise the question with Member States of a possible strengthening of the unilateral reduction commitment from 20 to 30\%. Some important Member States have supported this idea, but a number have shown little enthusiasm,

\footnotetext{
${ }^{14} \mathrm{Cf}$. Section 5 of the 2008 report

${ }^{15}$ http://ec.europa.eu/environment/climat/home_en.htm
} 
arguing that the recession gives little margin for being more ambitious than already agreed in the absence of a broader international consensus.

After the disappointing results of Copenhagen, less strong internal cohesion among Member States and a general weakening of the policies are in the process of tarnishing the image of the EU as the global leader in climate change.

As regards support to adaptation - an issue of no lesser interest for Arctic populations - work is under way in the Commission. A "white paper" while not addressing specifically the Arctic, advocates strengthening the dialogue with partner countries on adaptation issues, and supporting wider international efforts in the context of a comprehensive adaptation strategy. Work has started on a communication on "mainstreaming" adaptation in external EU policies.

Despite the fact that the Arctic was first given visibility in the EU as a region which deserved political attention in the March 2008 report to the European Council on climate change and international security, the security dimension has not been a prominent element in later pronouncements.

The December 2008 Recommendations of the High Representative on the follow-up to the above report ${ }^{16}$ had only a general mention the Arctic as a region where climate change will exacerbate existing drivers of instability and may lead to disputes and where studies should be undertaken; a more recent progress report and follow-up recommendations ${ }^{17}$, endorsed by the Council in December 2009, just mention the Arctic in connection with research on ice extent and new possible Arctic routes and refers to the Commission communication as providing strategic guidelines and concrete activities to facilitate the integration of climate change into external policies.

One may sense a reluctance to step into a situation increasingly sensitive and complicated internationally, not least because security issues are prominent in the Arctic strategies of the main Arctic - and world - players. The Commission communication addresses very obliquely the question, alluding to the need to follow closely the process of delimitation of national jurisdictions in the Arctic, while the Council simply states "maintaining the Arctic as an area of peace and stability” as one of the basis for its approach to the Arctic.

\footnotetext{
${ }^{16}$ http://www.consilium.europa.eu/uedocs/cms_data/docs/pressdata/en/reports/104895.pdf

${ }^{17} \mathrm{http}: / /$ register.consilium.europa.eu/pdf/en/09/st16/st16645.en09.pdf
} 


\subsubsection{Environment ${ }^{18}$}

Protection and preservation of the Arctic environment is the foremost objective of EU Arctic-relevant action (section 2.1. of the Commission communication and paragraphs 4, 5, 8, 9, 11 of the Council conclusions in particular), and the need to take into account environmental considerations imprints all the proposals made both in the Commission communication and the Council conclusions.

Chemicals, air pollution, biodiversity, marine environment protection, monitoring and assessment continue to be the most Arctic-relevant fields in the work of DG Environment (DG ENV) ${ }^{19}$. Though few specifically Arcticfocused actions have been undertaken, much greater attention is being given to the area and there is increased awareness of and sensitivity to the Arctic issue.

In recognition of the fact that environmental problems in the Arctic originate from the outside, DG ENV has launched an exercise aiming at identifying the "EU Arctic footprint" - a first attempt at assessing the contribution of the EU to the impact on the Arctic environment and inhabitants, as well as the effectiveness of EU policies in mitigating Arctic impacts. The project (Arctic Footprint and Policy Assessment) ${ }^{20}$, which will develop indicators and scenarios up to 2030, has the duration of one year, and a financing of $€ 250,000$.

The EU continues to participate actively in international action to protect biodiversity and to prevent pollution from land-based sources of POPs, heavy metals and other contaminants. In particular, the EU continues actively to support and work for a free standing multilateral environmental agreement on mercury ${ }^{21}$. The Council in its conclusions has invited the Commission to present a work plan on hazardous chemicals in the Arctic, using the REACH register of chemicals substances when useful.

As regards marine environment, in the framework of the European marine strategy, the EU has reaffirmed the importance of cooperation between countries sharing marine waters and of applying the ecosystem based approach as the overarching principle towards sustainable management. The

\footnotetext{
${ }^{18} \mathrm{Cf}$. Section 8 of the 2008 report

${ }^{19}$ http://europa.eu/pol/env/index_en.htm

${ }^{20}$ http://arctic-footprint.eu/

${ }^{21}$ http://ec.europa.eu/environment/chemicals/mercury/index.htm
} 
EU further supports the creation of a comprehensive network of marine protected areas, including beyond national jurisdiction, and in the Arctic region.

DG ENV is pursuing an exercise to identify and catalogue Arctic relevant projects. Moreover, a project to contribute to the establishment of a dialogue with NGOs on Arctic environmental issues is currently being tendered.

For its part, the European Environment Agency ${ }^{22}$ (EEA) continues to be active on Arctic issues. EEA notably produces its own reports but also takes part in the work of the Arctic Council working groups CAFF, PAME and AMAP, and participates, in the framework of its cooperation with the US and Canada, in studies on sea ice extent and thickness and on acidification in Arctic regions.

In 2010 EEA will publish the 4th State and Outlook report on the European environment, which will report on a number of Arctic aspects, including on biodiversity, climate change impacts and marine aspects. EEA is also, along with the government of Kazakhstan, working on the 5th assessment report on the environment of the wider pan- European region including the Arctic, in preparation for the next ministerial conference in the framework of the UNECE Environment for Europe process to take place in the autumn 2011.

Furthermore, the EEA has an important function of data coordination and dissemination, including of Arctic-relevant data, particularly through the European environment information and observation network (EIONET), which is an important building block in SAON. The EEA is also to be at the center of the Shared Environmental Information System (SEIS), a collaborative initiative currently being implemented with the Commission and the Member States to create an integrated and shared EU-wide environmental information system, which connects all the databases and makes them accessible. The EEA is similarly centrally involved in the Global Monitoring for Environment and Security (GMES) which covers the Arctic region.

Previously seen as a section of environment policy and part of DG ENV, civil protection is now a policy of its own right, subject of a dedicated Article (Article $196 \mathrm{TFEU}$ ). It is presently managed in the DG competent for Humanitarian Aid and Civil Protection (DG ECHO) ${ }^{23}$. While Member Sta-

\footnotetext{
${ }^{22}$ http://www.eea.europa.eu/about-us

${ }^{23}$ http://ec.europa.eu/echo/civil_protection/civil/prote/cp01_en.htm
} 
tes maintain their competence for civil protection, the EU supports, coordinates or supplements their action in order to improve the effectiveness of systems for preventing and protecting against natural or man-made disasters. The main potential importance for the Arctic continues to be via the civil protection mechanism, which acts in coordination with the European Maritime Safety Agency (EMSA), and deals inter alia with the response to oil spills in marine waters. Moreover, in the framework of the Barents cooperation, the Commission has actively supported a 2008 inter-regional agreement on emergency prevention, preparedness and response between Finland, Norway, Sweden and Russia, whereby exercises are organised on a regular basis. A preparatory action on a EU rapid response capability, designed to respond to critical needs arising from major disasters, includes developing a new urban search and rescue module in cold conditions, which could be useful in the Arctic region.

\subsubsection{Research $^{24}$}

Research, managed by DG $\mathrm{RTD}^{25}$ remains the sector where the Arctic dimension is most visible. The Commission communication (section 2.3) notes the need to maintain the Arctic as a priority area for the EU research effort and to improve internal EU coordination. The Council conclusions (in particular paragraphs 6 and 7) also emphasize the need for a systemic approach covering all Arctic-relevant aspects of research, as well as to promote better coordination and cooperation both within the EU and internationally, thus optimizing the use of resources.

The International Polar Year has represented a further incentive to EU research in the Arctic, which continues to focus on issues related to climate change

The main research project so far, DAMOCLES [http://www.damocleseu.org/], was extended to June 2010, with no further financing, principally to allow for the full integration and analysis in the final conclusions of the exceptional ice conditions of the summers 2007 and 2008.

Projects started in the period under consideration include:

\footnotetext{
${ }^{24}$ Cf. Section 7 of the 2008 report

${ }^{25}$ http://ec.europa.eu/research/
} 
ACOBAR [http://acobar.nersc.no/], to develop an observing system for the interior of the Arctic Ocean based on underwater acoustic methods (EU contribution $€ 3$ million over 2 years from November 2008 ; 9 partners)

- THOR [http://www.eu-thor.eu/] to establish an operational system to monitor and forecast the development of the North Atlantic thermohaline circulation to 2025 and assess its stability and the risk of a breakdown in a changing climate, taking into account inter alia the melting of the Greenland ice sheet ( EU €9.2 million ; 4 years from December 2008 ; 20 partners).

- ATP [http://www.eu-atp.org/] to identify the elements of the Arctic marine ecosystems likely to show abrupt changes following climate change and evaluate the consequences of crossing such tipping points (EU nearly $€ 5$ million ; 3 years from February 2009; 13 partners)

- Ice2sea [http://www.ice2sea.eu/], to estimate the future contribution of continental ice melting, including ice caps in Svalbard and Greenland's ice sheet, to sea level rise ( EU nearly €10 million; 4 years 3 months from March 2009; 24 partners)

Two projects, ARCRISK [http://www.arcrisk.eu/] (EU €3.5 million; 4 and a half year from June 2009; 21 partners) and CLEAR (http://www.inuendo. $\mathrm{dk} /$ clear/) (EU nearly €2.4 million; 4 years from May 2009; 8 partners), study impacts on human health and reproductive human health respectively of exposure to environmental contaminants depending on climate change, comparing Arctic and selected European populations .

Other ongoing research projects do not target specifically the Arctic region, but include research in Arctic areas in a wider area of research. Examples are ESONET and EuroSITES, which aim at creating an operational network of ocean observatories; HERMIONE, an interdisciplinary study of the functioning of deep-sea ecosystems and their contribution to the economy, CoralFISH, which studies the interaction between fish and cold-water coral habitats and DS 3F, which aims at better understanding of deep-sea and sub-sea-floor processes with a view to sustainable management of ocean resources at the European scale

Furthermore, under the FP 7 Ideas Programme, managed by the European Research Council, a project (MATRICS) aims at developing modern 
approaches to temperature reconstructions in polar ice cores (EU €2.1 million; 5 years from January 2009)

Finally, an important cross-thematic joint call on marine and maritime research "The Ocean of tomorrow" launched mid-2009 and in the process of being attributed, includes a topic "Quantification of climate change impacts on economic sectors in the Arctic". With a foreseen EU contribution of up to $€ 11$ million, the research will aim at assessing those impacts and providing scientific basis for the sustainable development of human activities in the region.

As regards research infrastructures, the European Strategy Forum on Research Infrastructure (ESFRI) ${ }^{26}$ has included in its updated roadmap support for the preparatory phase of the Svalbard Integrated Arctic Earth Observing Facility (SIOS) ${ }^{27}$, due to start in autumn 2010. The EU support is foreseen to be around $€ 4$ million for a planned upgrade of the present infrastructure on Svalbard, aiming at integrating the studies of geophysical, chemical and biological processes from all research and monitoring platforms to monitor global environmental change. The SIOS, planned to become operational in 2012, would be one of the building blocks of SAON.

The EU-financed preparatory phase for the construction of the icebreaker, drilling platform and multi-purpose research vessel Aurora Borealis $^{28}$ is under way and will be concluded at the beginning of 2012 .

For its part, the Joint Research Centre has recently published the Soil Atlas of the Northern Circumpolar Regions ${ }^{29}$, intended to be used as a valuable tool for several types of Arctic studies.

\section{2...in unison with the Arctic population}

The issues which continue to polarise negative feelings towards the EU, particularly for Arctic indigenous peoples but also for some Arctic state governments such as Canada and Norway, are those linked to animal welfare ${ }^{30}$

\footnotetext{
${ }^{26}$ http://ec.europa.eu/research/infrastructures/index_en.cfm?pg=esfri

${ }^{27}$ http://www.forskningsradet.no/servlet/Satellite?c=Page\&cid=1234130481137\&pagename $=$ sios $\% 2$ FHovedsidemal

${ }^{28}$ http://www.eri-aurora-borealis.eu/

${ }^{29}$ http://eusoils.jrc.ec.europa.eu/library/maps/Circumpolar/index.html

${ }^{30} \mathrm{Cf}$. Section 7 of the 2008 report
} 
The Lisbon Treaty has introduced among the provisions of general application a new Article (Art 13 TFEU), which requires that full regard be paid to the welfare of animals in the formulation and implementation of relevant EU policies, reproducing an reinforcing a previous Protocol to the Treaty.

The most controversial issue is the ban on imports of seal products, adopted in September 2009 by the European Parliament and the Council ${ }^{31}$ as a result of widespread campaigning in the EU, which had led to the introduction of import restrictions by some Member States, and to the intervention of the European Parliament requiring action by the Commission. The Commission, having identified as the main question the perceived cruelty in the way seals were killed and skinned, proposed in 2007 a combination of trade ban, agreements with third countries, and labeling. The proposal provided that the trade of seal product be banned, except from countries where legislation ensuring that the seals would be killed without causing avoidable pain, distress and any other form of suffering existed and was effectively enforced; and an appropriate certification scheme be established. The final decision of Council and Parliament however - contrary to what usually happens - went further than the Commission had proposed, in that it banned the placing on the market of all seal products, irrespective of their origin, except when such products

"result from hunts traditionally conducted by Inuit and other indigenous communities, and contribute to their subsistence”.

While the legal basis of the regulation is trade policy - therefore susceptible to challenges in WTO, which Canada has already launched ${ }^{32}$ - the preamble makes it clear, on the one hand, that animal welfare considerations are paramount, and, on the other hand, that

\footnotetext{
${ }^{31}$ Regulation on trade on seals product 1007/2009 - OJ L 286 of 31.10.2009, p.36. For text and background see http://ec.europa.eu/environment/biodiversity/animal_welfare/seals/ seal_hunting.htm

${ }^{32}$ A case against the ban has also been brought to the EU General Court by a number of applicants, including two indigenous peoples'organisations
} 
"the fundamental economic and social interests of Inuit communities engaged in the hunting of seals as a means to ensure their subsistence should not be adversely affected”

insofar as

"the hunt is an integral part of the culture and identity of the members of the Inuit society”.

The "Inuit exception" had not helped avoiding the collapse of the seal products market when the EU in 1983 banned imports of baby seals products, and is not helping now assuaging the fears and calming the animosity of Arctic inhabitants. The strict conditions and rather cumbersome administrative requirements laid down for managing the exception ${ }^{33}$ do not seem to help either. Accusations of insensitivity to the needs and traditions of Arctic populations, in particular indigenous peoples, continue to be brought against the EU.

Whaling is an issue which concerns local populations of Iceland and Norway as well as some Arctic indigenous peoples. Cultural traditions, economic importance in regional or local economies with limited resource bases, environmental sustainability, are arguments brought with different accents by Icelandic and Norwegian governments as well as by the Danish government on behalf of Greenland's interests, in support of the continuation of whaling in the Arctic.

A decision adopted by the Council in March 2009 established the basic tenets of the EU position for the next three annual meetings of the International Whaling Commission. 25 EU Member States are currently members of the IWC while the EU, represented by the Commission, has observer status. The EU position in the IWC has remained consistent with the one adopted in $2008^{34}$. The overarching objective remains to ensure an effective regulatory framework for the conservation and management of whales, that would guarantee a significant improvement in their conservation status in the long term and bring all whaling operations under IWC. The moratorium on commercial whaling remains a key tool to this effect. The EU continues to sup-

\footnotetext{
${ }^{33}$ http://eur-lex.europa.eu/LexUriServ/LexUriServ.do?uri=OJ:L:2010:216:0001: 0010:EN:PDF

${ }^{34} \mathrm{Cf}$. box page 73 of the 2008 report
} 
port the possibility for indigenous peoples to continue whaling under certain conditions; it joined in the consensus on revised Greenland quotas achieved in June 2010. Denmark maintains a distinct balanced position in the negotiations - different both from the anti-whaling policy of the EU and from the positions of whaling countries - in safeguard of the interests of Greenland and of the Faroe Islands.

Section 2.2 of the Commission communication reflects in its formulation an uneasy effort to conciliate the EU position as promoter and defender of indigenous peoples rights ${ }^{35}$ on the one hand and as first-liner in action against traditional and economically significant pursuits of Arctic indigenous peoples as well as of other local communities on the other hand. The solution proposed is dialogue. The Council for its part, having stated that the respect of the Arctic environment as well as of the needs and rights of its residents has to be one of the bases for EU action, steers clear of specific references to the controversial sealing and whaling issues, and prefers general language, welcoming in particular the idea of a broad dialogue with Arctic indigenous peoples (in particular paragraph 3).

An "Arctic dialogue" workshop was organized by the Commission in March 2010 for representatives of Arctic indigenous peoples' organisations, with the participation of representatives of Arctic governments, rather as a brain-storming exercise than as a consultation on concrete proposals ${ }^{36}$. Commission representatives took part in the April 2010 Arctic indigenous leaders Summit, and in the June 2010 General Assembly of the Inuit Circumpolar Conference. Final declarations from both meetings, which addressed principally the indigenous peoples worries and expectations following the new industrial and resource developments in the Arctic, acknowledged the desirability of enhancing dialogue with the EU. The ICC was however requested to

\footnotetext{
"fight unethical and unfair trade restrictions placed on our own products including the unjust European Union action to ban seal and other marine mammal product",
}

signaling that EU action in this particular field is not forgotten nor forgiven.

\footnotetext{
${ }^{35} \mathrm{Cf}$. Section 10 of the 2008 report

${ }^{36}$ http://ec.europa.eu/maritimeaffairs/pdf/arctic_workshop_090310_summary_en.pdf
} 
There appears to be a widespread worry among Arctic indigenous peoples that EU public opinion will attack on other fronts their traditional ways of exploiting natural resources, possibly leading to other EU initiatives detrimental to their economic interests and cultural traditions.

\subsection{Promoting sustainable use of resources}

\subsubsection{Energy $^{37}$}

After more than 30 years of EU activity in the field of energy, the Lisbon Treaty has finally recognised energy policy as a EU policy in its own right managed by a dedicated DG ENER ${ }^{38}$. The new article (Art. 194 TFEU) basically codifies the existing situation, in that it recognises the strong links with internal market and environment, on which EU energy policy has been based so far. The newer elements are the formal addition of security of supply as a policy objective, and the reference to the spirit of solidarity between Member States. The Member States' right to decide conditions for exploiting their energy resources as well as their right to decide on their national energy mix is maintained.

Contrary to oil supply, which is basically a global issue, gas supply is still very much a regional issue, and as such of particular relevance in a EUArctic context. The particular vulnerability of the $\mathrm{EU}$ as regards gas security of supply was already the main concern raised in the November 2008 Commission's Second Strategic Energy Review. Much of the concern has since evaporated, following technological developments in North America that have made available to the EU all liquefied natural gas in the Atlantic Basin, and as a consequence of the recession which has led to a significant reduction in EU gas consumption and in expected future import needs. These developments have turned the EU gas market into a buyers' market, with depressed prices, and may be instrumental - along with increased environmental worries following the oil spill in the Mexican Gulf - in slowing down expensive exploration and/or production projects in the Arctic, as it has happened with the Russian Shtokman field.

\footnotetext{
${ }^{37}$ Cf. Section 6 of the 2008 report

${ }^{38}$ http://ec.europa.eu/energy/index_en.htm
} 
In a longer time perspective, however, Arctic gas resources are of interest to the EU energy market, as domestic EU resources are insufficient to cover future needs, particularly as natural gas offers the most cost-effective alternative to more environmentally polluting coal. Russia and Norway account presently for the greatest part of imports of gas - as well as of oil - in the EU and external energy relations are of great importance in energy policy. The EU-Russia energy dialogue ${ }^{39}$, working towards a strategic EU-Russia energy partnership to ensure security of supply, and the EU-Norway energy dialogue $^{40}$ are the frameworks in which issues related to exploration of energy resources in the high north are treated. While the focus is not for the time being Arctic-specific there is dialogue and exchange of information on investments in exploration, exploitation and commercialization on a 10-15 year perspective.

Consultation is open in the EU on a new energy strategy 2011-2020.

The Commission communication (section 3.1) stresses the importance of observing strict environmental standards in the exploitation of Arctic resources and proposes enhancing long term cooperation particularly with Russia and Norway, including on research in offshore technology and infrastructure. In a politically savvy statement, the Council welcomes in its conclusions (paragraph 4) the commitment and effort of Arctic states in jointly striving to minimize negative environmental impacts of exploitation and use of natural resources in the Arctic, signaling EU full awareness of the rights of coastal states in the exploitation of hydrocarbons and of other resources.

\subsubsection{Maritime affairs and fisheries}

DG MARE is competent for maritime affairs ${ }^{41}$ and fisheries ${ }^{42}$. Maritime affairs is a relatively new concept in EU policies, covering a number of diverse elements - some concrete actions and some more abstract - and has as its main framework the Integrated Maritime Policy (IMP) ${ }^{43}$. While the IMP has a predominantly internal EU dimension, marine ecosystems and economics transcend boundaries, adding an obvious external dimension. In its

\footnotetext{
${ }^{39}$ http://ec.europa.eu/energy/international/bilateral_cooperation/russia/russia_en.htm

${ }^{40} \mathrm{http} / / /$ ec.europa.eu/energy/international/bilateral_cooperation/norway_en.htm

${ }^{41}$ http://ec.europa.eu/maritimeaffairs/mp_dev_en.html

${ }^{42}$ http://ec.europa.eu/fisheries/index_en.htm

${ }^{43}$ Cf. Section 9.1 of the 2008 report
} 
October 2009 progress report on the IMP, the Commission lists a number of areas requiring international solutions, such as the protection of biodiversity, maritime safety and security, and marine research. The IMP was where the idea of a report on Arctic issues was first mooted, and the Arctic communication is viewed as constituting one of the IMP's regional approaches. In fact, the Directorate "Atlantic, Outermost Regions, and Arctic" acts as a coordinating entity for EU action, principally, but not exclusively, regarding the Arctic Ocean.

The question of Arctic fisheries ${ }^{44}$ is mainly viewed at this stage as part of the more general issue of ensuring a sustainable exploitation of Arctic marine living resources. Both the Commission communication (section 3.2 ) and the Council conclusions (paragraphs 10 and 11) stress the need to protect the marine environment, in particular marine biodiversity in areas beyond national jurisdiction, and to manage the exploitation of such resources in an ecosystem perspective, through action to be pursued within bilateral and multilateral existing frameworks. They recommend a precautionary approach to new fishing opportunities in the Arctic high seas which would arise following climate change, notably a temporary ban on new fisheries in those waters, until a regulatory framework for management and conservation is put in place, ideally by extending the mandate of existing management organisations such as NEAFC. The EU has presented proposals to this effect, but for the moment there does not appear to be readiness to start discussions.

\subsubsection{Maritime transport ${ }^{45}$}

While the EU as such has limited competence in this field, maritime transport is arguably the area where EU interest in the potential opportunities of a largely ice-free Arctic Ocean is clearer, as recognized in the Commission communication (Section 3.3). The Council conclusions (paragraph 12 to 16) also cover this aspect quite extensively, underlining inter alia the importance of work being done in IMO and in the Arctic Council to improve existing Arctic navigation regulations and standards, and inviting Member States and the Commission to work towards extending cooperation in the region as

\footnotetext{
${ }^{44}$ Cf. Section 9.2 of the 2008 report

${ }^{45} \mathrm{Cf}$. Section 9.3 of 2008 report
} 
regards monitoring and information systems, operational assistance in pollution prevention and response, search and rescue and other emergency purposes. The Council underlines further the obligation for Member States to monitor the full implementation of existing rules, while reiterating coastal states' rights and obligations as regards freedom of navigation as well as rights of innocent and transit passage.

Accordingly, DG MOVE, competent for EU maritime transport policy ${ }^{46}$, has stepped up considerably its attention to the Arctic area. A 2009 Commission communication which defines the main strategic objectives of the European maritime transport policy to 2018 recognizes inter alia the place of maritime transport as a key element of EU energy security, and reiterates the need to work to ensure sustainable Arctic navigation, including by ensuring appropriate ice navigation and construction standards and assistance requirements.

Maritime safety remains the main Arctic relevant activity for the Commission. The Commission is an observer in work for the development of a mandatory IMO code for ships operating in polar waters. The European Maritime Safety Agency (EMSA) ${ }^{47}$ which has inter alia operational tasks in oil pollution preparedness, detection and response, is being gradually involved in the work of PAME.

It has further to be noted that the Northern Maritime Corridor project, aimed to facilitate shift of cargo from road-based to sea-based transport, is extended to 2011 and expanded to the Barents region, under the name of StratMos $^{48}$. The project is financed jointly by Norway and the EU programme INTERREG IV B ${ }^{49}$.

If commercial maritime transportations opportunities for the EU in the Arctic are still at this stage potential, or at most embryonic, cruise-ship tourism is a sector expanding at significant pace. The Commission communication has a section on tourism in the Arctic (section 3.4), which focuses on this rapid development.

Tourism is another policy field to which the Lisbon Treaty has given a legal basis (Article 195 TFEU). The EU complements action by Member States, which retain exclusive competence, by promoting the competitive-

\footnotetext{
${ }^{46} \mathrm{http}: / /$ europa.eu/legislation_summaries/transport/waterborne_transport/index_en.htm\#

${ }^{47} \mathrm{http} / / /$ www.emsa.europa.eu/

${ }^{48} \mathrm{http}: / /$ www.stratmos.no/stratmos/public/openIndex?ARTICLE_ID=100

${ }^{49} \mathrm{Cf}$. Section 3 of the 2008 report
} 
ness of EU undertakings and cooperation between the Member States, particularly by the exchange of good practice.

As well as action aimed at a better safety of ships, the Commission in the communication highlights the importance of the preservation of the environment and the involvement of local communities. 



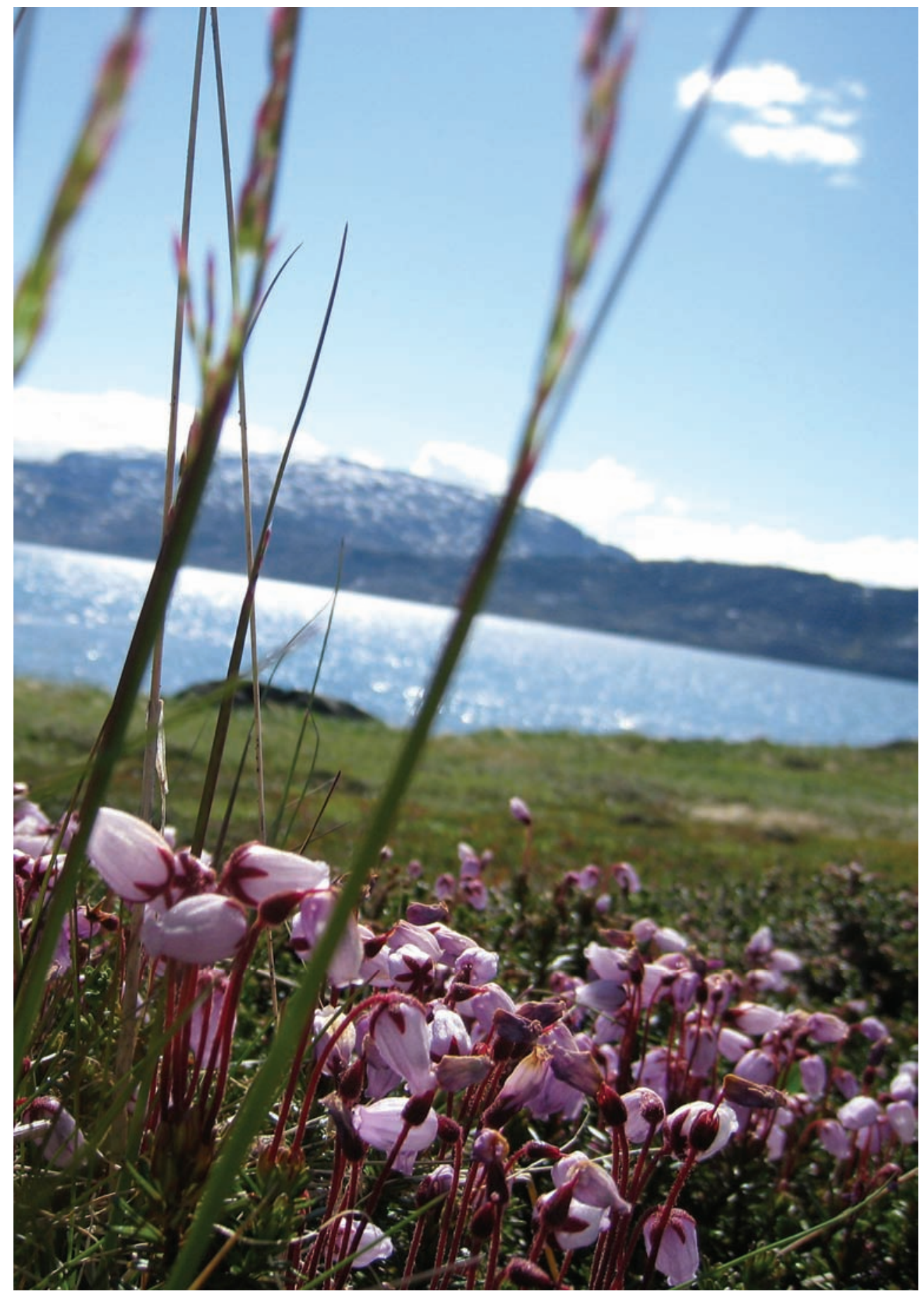




\section{The EU in the Arctic political context}

The EU contribution to enhanced Arctic governance in the Arctic, as identified by the Commission and confirmed by the Council (cf. also section 2 of this paper), is to be based on the full implementation and strengthening of relevant agreements, frameworks and arrangements at all levels, first and foremost UNCLOS.

Section 4 of the Commission communication suggests, with deliberately cautious language, specific ways the EU could consider to make its presence felt in the Arctic context. The Council conclusions (paragraphs 17 to 22) review the place of the EU in the Arctic, with some suggestions for enhancing Arctic aspects in relevant fora and bilateral relationships.

This section sets out the main lines of the evolution of the EU position in multilateral cooperation in the Arctic, as well as of Arctic-relevant aspects in EU's bilateral relations with non-EU Arctic states or territories.

Finland is arguably the EU Member State most keen on an increased EU presence in Arctic affairs. The June 2010 Finland's Arctic Strategy ${ }^{50}$ has reaffirmed Finland's repeated calls for a stronger, more specific and ambitious EU Arctic policy. The strategy identifies the Northern Dimension (see below) as a useful tool to this end, and suggests that the ND's Arctic Window become a central element of the EU Arctic policy, particularly through injecting greater consideration of specific Arctic characteristics in the partnerships, using efficiently the existing programmes, and enhancing cooperation on Arctic matters with the other regional councils as well as with Canada and the US.

Finland is furthermore actively promoting the establishment of a Euro-

${ }^{50}$ http://www.valtioneuvosto.fi/ajankohtaista/tiedotteet/tiedote/en.jsp?oid=297821 
pean Arctic information centre, with the double function of providing Arctic information to EU citizens and to make EU policies and activities more visible externally, in the Arctic and beyond. The Council (paragraph 22) had invited Member States, to examine the merits of establishing such a centre together with the Commission, which had suggested considering this possibility in its communication..

\subsection{The Northern Dimension ${ }^{51}$}

The "new" Northern Dimension" ${ }^{52}$, as agreed in 2006, has a special place in the EU system, as it lies at the intersection between a EU policy and wider international cooperation ("a common project and a common responsibility" of four partners, the EU, Iceland, Norway and Russia, with the involvement of a number of other participants and actors - from the other northern regional Councils to local authorities, to indigenous peoples - and with Canada and the US as observers).

Partnerships, where projects are co-financed as a rule by the partners and by international and private financial institutions, remain the privileged forms of cooperation in the ND. The ND Environmental Partnership $(\mathrm{NDEP})^{53}$ and the ND Partnership in Public Health and Social Well Being (NDPHS) $^{54}$ are thriving. The ND Partnership for Transport and Logistics (NDPTL), launched in 2009 and planned to be operational by 2010, aims at promoting international trade and sustainable economic growth, by improving the major transnational transport connections, accelerating the implementation of infrastructure projects and facilitating the elimination of bottlenecks. In 2009 it was further agreed to establish a ND Partnership on Culture (NDPC), which should function as a focal point for networks, projects and other cultural activities in the ND region, promoting coordination and cooperation between the four regional councils participants in the ND and facilitating the dialogue between cultural operators and the business community. The possibility of establishing a partnership on energy has also been touted.

\footnotetext{
${ }^{51}$ Cf. Section 2.1 of the 2008 report

52 http://ec.europa.eu/external_relations/north_dim/index_en.htm

${ }^{53}$ http://www.ndep.org/home.asp

${ }^{54}$ http://www.ndphs.org/
} 
In addition, a ND Institute (NDI) ${ }^{55}$, a network of universities and research institutes with expertise in the priority sectors of the ND, has been established; a ND Business Council (NDBC) is being developed to create a platform for dialogue between companies and the public authorities.

The partnerships, particularly the NDEP, are very active in the Barents region, and to this extent, justify the indication of the "extensive Arctic and sub-arctic" as priority areas in the ND. The 'Arctic window', promoting cooperation on issues concerning the whole circumpolar Arctic region, continues to be a feature of the ND. Political pronouncements, starting from the 2008 joint statement of ND Ministers, underline the desirability for greater ND involvement on Arctic issues.

The Council in its conclusions (paragraph 20) encourages the development of the ND Arctic Window and notes in particular that further consideration would be needed on how indigenous peoples could be included in the deliberations on the Arctic Window. It warns, however, that attention should be paid to avoid duplicating work within the mandates of the Arctic Council or the Barents Euro-Arctic Council. This is a recognized problem in Arctic cooperation - the First ND Parliamentary Forum in February 2009 also issued a call for better coordination between regional Councils in the Arctic.

The potential and the will for a greater presence and consideration of the Arctic element appear therefore to exist and ways to achieve this aim are presently being considered in the preparation of the next ND ministerial meeting scheduled for the autumn 2010.

\subsection{The multilateral framework ${ }^{56}$}

\subsubsection{Barents Euro-Arctic cooperation}

Finland, Norway and Russia, for obvious reasons, are the main actors in the Barents region and consistently underline the importance they attribute to a strong Barents dimension of Arctic cooperation.

While the Commission was one of the founding members of the Barents Euro-Arctic Council, the EU is not a core participant in BEAC as such, as

\footnotetext{
${ }^{55}$ http://www.ndinstitute.org/

${ }^{56}$ Cf. Section 2.2 of the 2008 report
} 
reflected in the language on Barents cooperation in paragraph 21 of the Council conclusions.

However, the EU has a strong presence in the Barents region, both with cross-border regional programmes and in the framework of the Northern Dimension partnerships.

In the light of the new interest of the EU for the high north and of the EU general desire for a stronger relationship with Russia, a greater involvement in the successful and growing regional cooperation could be an asset. The International Barents Secretariat, established in 2008, sees such a development as potentially leading to a central role of the EU in the Barents cooperation, provided that greater coordination of activities and initiatives with other regional organizations operating in the north be achieved, and multilateral project financing be promoted ${ }^{57}$. In this perspective, the Barents cooperation could become an alternative arena for an enhanced EU role in the Arctic.

\subsubsection{Arctic Council}

Three EU Member States (Denmark, Finland and Sweden) are full Members of the Arctic Council and six (France, Germany, Netherlands, Poland, Spain and the United Kingdom) are permanent observers.

One of the proposals contained in the Commission Communication was to

"enhance input to the Arctic Council in accordance with the Community's role and potential. As a first step, the Commission will apply for permanent observer status in the Arctic Council”.

The EU Council welcomed this decision in its conclusions of December 2008, and in the same month the Commission addressed a formal application. At its meeting of April 2009, the Arctic Council of Foreign Ministers, which meets every two years and is competent for taking decisions on such applications, was not able to finalise its discussion on the role of observers, which it decided to continue. The Commission's application, together with those of Italy - another EU Member State - China and South Korea, and the

\footnotetext{
${ }^{57}$ See Barents Review 2010 - Talking Barents http://www.barents.no/ barents-review.141647.en.html, page 28 in particular
} 
later application of Japan and Singapore, remain on the table, and will be discussed again at the next Foreign Affairs Ministerial meeting in April 2011.

In its December 2009 conclusions (paragraph 17) the EU Council states that it
"recognises the Arctic Council as the primary competent body for circumpolar regional cooperation and expresses its continued support for the applications by Italy and the Commission to become permanent observers in that body. The Council encourages Member States, and the Commission together with the EEA to continue to contribute to the work of relevant Arctic Council working groups."

The Council also praises the work of the Arctic Council, particularly the Arctic Marine Shipping Assessment, and invites Commission and Member States to consider endorsing the AC Offshore Oil and Gas Guidelines.

Pending a decision, the Commission continues to take part in Arctic Council meetings at Senior Arctic Officer and Ministerial level on an ad hoc observer basis. Together with the EEA, it contributes to the work of some Arctic Council Working Groups.

\subsubsection{Nordic Council of Ministers}

The Conference "Common Concern for the Arctic" held in Ilulissat in September 2008 provided a forum for exchange of views on Arctic-relevant policies and activities pursued by states and the EU. It explored new challenges and opportunities in a number of policy areas and the role of circumpolar and regional cooperation in the region, with a view to enhance synergies in the implementation of such policies and activities ${ }^{58}$.

In May 2010, a NCM Conference “Arctic - Changing Realities” sought to identify more closely possible responses to the need to adapt to the changes in the region and better to define the contribution of the NCM to sustainable development in the Arctic.

The NCM Arctic co-operation programme $2009-2011^{59}$ is a platform for Nordic cooperation on Arctic questions with the countries within Arctic

\footnotetext{
${ }^{58}$ http://www.norden.org/da/publikationer/publikationer/2008-750/

${ }^{59}$ http://www.norden.org/en/nordic-council-of-ministers/council-of-ministers/council-ofministers-for-the-environment-mr-m/strategy/the-nordic-council-of-ministers-arctic-cooperation-programme-200920132011?set_language=en
} 
Council and neighbours. The programme seeks to contribute to an increase in knowledge on climate change, pollutants and heavy metals; to develop and improve the quality of life of the Arctic residents; to support the Arctic populations' social and cultural development and to preserve the Arctic biodiversity and nature. The Arctic Cooperation Programme explicitly refers to co-operation with the EU - including on the development of the Arctic Window in the EU's Northern Dimension. The NCM together with Canada leads a working group on indigenous health under the Northern Dimension's health partnership.

A NCM-EU workshop, aimed at establishing closer links and identifying areas of cooperation where concrete projects could be implemented with synergetic effects, is foreseen to take place in October 2010.

\subsection{Bilateral relations}

The Council conclusions (paragraphs 18 and 19) gave a clear indication that the EU should actively seek consensus approaches to Arctic issues through cooperation with Arctic states and territories outside the EU, stressing in this connection the strong links with Greenland, as well as with Iceland and Norway as members of the European Economic Area ${ }^{60}$.

\subsubsection{Greenland}

A very important development which took place in the period under consideration is the entry into force of the Act on Greenland Self-Government ${ }^{61}$ on 21 June 2009. Greenlanders are now recognized as a people according to international law, with rights of self-determination, and a gradual further transfer of powers and responsibilities from Denmark to Greenland is to take place. Already in 2010 Greenland has assumed responsibility for the control and use of mineral and oil resources.

Foreign affairs, together with defence and security policy, monetary policy, and other areas of fundamental importance for defining the unitary cha-

\footnotetext{
${ }^{60} \mathrm{Cf}$. Sections 12 of the 2008 report for Greenland and Section 2.3 for Iceland and Norway

${ }^{61}$ http://uk.nanoq.gl/sitecore/content/Websites/uk,-d-,nanoq/Emner/Government/ /media/ F74BAB3359074B29AAB8C1E12AA1ECFE.ashx
} 
racter of the state of Denmark, remain Denmark's competence. Greenland has been given competence, under certain conditions, in areas where it has assumed responsibilities, such as fisheries, where it can conclude international agreements in its own right. It also has increased saying in international agreements entered by Denmark, with the possibility in principle to require not to be bound by those agreements. It has been observed that the fact that Denmark is a member of the EU - bound therefore by agreed EU common positions in international negotiations - while Greenland is not a EU member, may give rise to problems. In climate policy, as an example, Greenland argued against taking up the same obligations agreed by the EU, as it considered that its situation was nearer to that of developing countries.

The formal relations between EU and Greenland have remained unchanged from those described in the 2008 report. Greenland maintains the status of OCT (Overseas Countries and Territories) and as such has access to a number of EU programmes. In addition, it maintains its two-fold partnership with the EU. Under the Fisheries Partnership Agreement Greenland receives a financial contribution of $€ 15.8$ million per year (plus approximately €2 million from licence fees from ship-owners) in exchange for fishing opportunities in its waters - about $25 \%$ of this contribution being earmarked for the continued promotion of sustainable and responsible fishing. Furthermore, a bilateral partnership, with an annual allocation of $€ 25$ million, supports sector policies and strategies that facilitate access to productive activities and resources, in particular education and training, mineral resources, energy, tourism and culture, research and food safety. Greenland has selected education and training as the first focal sector for cooperation. A midterm review is due.Both partnership agreements expire at the end 2013 and will have to be renegotiated.

It is obviously too early to assess whether and how the new status of Greenland - which coincided with the establishment of a new government will influence the Greenlandic attitude to the EU, and its relations to other international partners. The direction and the intensity of Greenland's economic development will be a crucial element in this context. Greenland has already now enhanced its role in the Nordic cooperation.

As regards a EU policy on Arctic issues, Greenland has signaled that it welcomes action by the EU in the Arctic, particularly as regards control of transboundary pollutants and maritime issues, as well as a more active EU participation in Arctic cooperation, including through adequate financial 
tools. It would, however, wish greater attention to and consideration for the traditions and lifestyle of Arctic peoples and their rights to exploit their resources in a sustainable manner, in a relationship based on mutual respect and the recognition of mutual interests.

\subsubsection{Iceland}

Iceland is developing a new strategy on the High North, which it has recently defined as a key priority area of its foreign policy, with the objective inter alia to be recognised as an Arctic coastal state and key stakeholder in the development of the area.

In line with this position, Iceland believes that a future membership in the EU - for which it submitted an application in July $2009^{62}$ - would bring a substantial contribution to the EU Arctic policy, in that it would give the EU a geographical foothold in the region and strengthen common interests in the High North, in addition to broadening security arrangements in the region.

Iceland's application received a favorable opinion by the Commission in February 2010. In the analytical report accompanying the opinion, the Commission, after signaling inter alia that Iceland would need to align its legislation as regards the protection of whales and the ban on imports of seals products, notes that Iceland could play a significant role in the development of EU's policy in the Arctic. Public statements by representatives of the Commission and the Council have underlined that Iceland's accession would mean a stronger EU in its dealing with the Arctic region.

The European Council of June 2010 decided the opening of accession negotiations.

In a resolution adopted in July 2010 which welcomes the decision ${ }^{63}$, the European Parliament recognizes Iceland's responsible and sustainable management of marine resources - insisting however that it has to cease all whaling- and considers

"Iceland's accession to the EU - inasmuch as it will further anchor the European presence in the Arctic Council - as a strategic opportunity for the EU to play a

\footnotetext{
${ }^{62}$ http://europe.mfa.is/sidemenu/key-documents/

${ }^{63} \mathrm{http}: / /$ www.europarl.europa.eu/sides/getDoc.do?pubRef=-//EP//TEXT+TA+P7-TA-20100278+0+DOC $+\mathrm{XML}+\mathrm{V} 0 / / \mathrm{EN} \&$ language $=\mathrm{EN}$
} 
more active and constructive role, and also to contribute to multilateral governance, in the Arctic Region; 'pointing out' that this will help in tackling environmental issues of common concern and could heighten EU interest in the Arctic and its protection at regional and international level”

Negotiations started at the end of July 2010. Fisheries and whaling are widely regarded as among the more problematic areas.

The decision on the application is taken unanimously by the Council after consulting the Commission and after consent of the European Parliament, which acts by the majority of its components. The conditions of admission resulting from the negotiations are incorporated in a draft Accession Treaty which has to be ratified by all Member States and the applicant State. Iceland has announced that it will submit the final Accession Treaty to a referendum.

It may also be noted that the Lisbon Treaty has introduced a provision on the voluntary withdrawal of a State from the EU (Article 50 TEU), a clause which, as it has been observed, reinforces the concept that the EU is a voluntary association between states, which remain sovereign as to whether they want to remain in that association.

\subsubsection{Norway}

The 2006 Norwegian government's High North strategy has been followed and integrated in 2009 by a series of "new building blocks", with a time horizon of 10-15 years. The High North, from one of the most important priorities, has become "the most important strategic priority area" - the region where Norway has the most important interests to safeguard and the responsibility and ability to make a difference. As for relations with other countries, the main declared political priority is building a constructive partnership with Russia, in particular as regards co-management of resources - a successful strategy, as the recent border agreement for the disputed Barents Sea area has proven. In this perspective, and while Norway's links with the EU remain strong in the EEA, the EU is not a particular focus of Norway's High North strategy.

A visit to Brussels of Norway's prime minister in June 2010 was the occasion for both the President of the Commission and of the Council to stress the importance of shared objectives and common interests warranting an 
active cooperation of EU and Norway on Arctic issues, in the framework of a "deepened multilateral arctic policy".

Beyond the continuing cooperation with the EU in several sectors of relevance for the Arctic, in particular research and environment, Norway appears to recognize that the EU as a global actor has legitimate interests in and can make valuable contributions on Arctic issues, by enhancing its action for the sustainable development of the region, including through financial support. While reaffirming the central role of the Arctic Council for cooperation in the region, Norway therefore welcomes a more formalised involvement of the EU in its activities. It underlines, however, the importance for the EU to arrive at a better understanding of the situation in the High North - a reference, inter alia, to the EU positions on sealing and whaling, which Norway opposes, firmly siding with other Arctic states. On these issues, Norway maintains that the crucial criterion in the harvesting of living resources is science-supported sustainability, and that unilateral measures based on different criteria, which counter cultural traditions and impair the livelihood of Northern populations, are unjustified.

\subsubsection{Canada}

Arctic issues continue to be a difficult point in the relations between the EU and Canada. After the baby- seals legislation in the 1980ies, and the leghold traps legislation in the 1990ies, there is a sense of déjà vu, as the ban on seal products - seen as yet another undue and unjustified EU interference in the Canadian ways - caused growing irritation in an otherwise fairly harmonious relationship. This irritation was barely masked by diplomatic language in the communiqué issued after the October 2008 EU/Canada summit, which, after reiterating shared interest and objectives for the Arctic and the North and pledging for a joint progress report on Arctic cooperation - still in preparation - attempted to find conciliatory language in the affirmation of a common commitment to the well-being of all animals.

Attempts at conciliation having failed, the May 2009 summit resorted to very general language, by which, having recognized challenges and opportunities faced in the Arctic, the EU and Canada agreed

\footnotetext{
"to maintain a bilateral dialogue and cooperate on Arctic issues, with a focus on research and the concerns and interests of Arctic peoples and communities.”
} 
In fact, just before the meeting, Canada had widely been reported as the main opponent to the Commission's application to become a permanent observer in the Arctic Council, as the EU had failed to show "the required sensitivity" for involvement in Arctic issues.

While the Arctic was not mentioned in the communique following the EU/Canada summit in May 2010, a resolution on the upcoming summit adopted by the Parliament in the same month underlined the importance of EU and Canada to continue pursuing climate change related action and discussions on environmental issues

“including environmental, energy and maritime cooperation in the Arctic Zone and the prospects of initiating international negotiations for the adoption of an international treaty for the protection of the Arctic"

- this last words arguably not a helpful contribution for appeasing Canadian sensitivities about a EU role in the Arctic.

Canada has stressed, in its 2009 Northern Strategy and subsequent political pronouncements, that international cooperation in the Arctic has to be based on recognition of sovereignty and respect for northern values, and it has to be a means to sustainable development rather than an end in itself. The Arctic Council continue to be considered by Canada as the foremost forum for Arctic cooperation, and the other circumpolar states as privileged partners $^{64}$.

\subsubsection{Russian Federation}

The importance of economic links of the EU with the Russian Arctic region, particularly in the field of energy, has already been stressed. EU's partnership links with Russia in the region continue also to be strong.

In addition to the activities within the Northern Dimension, cross-border cooperation ${ }^{65}$ in the region remains a key priority in the framework of the EU regional/cohesion policy. DG AIDCO (EuropeAid Cooperation Office) manages two joint operational programmes - Kolarctic and Karelia - of

\footnotetext{
${ }^{64}$ The Statement on Canada's Arctic Foreign Policy, issued in August 2010, is the latest quite blunt reminder of the fact that Canada is not ready to compromise on these positions

${ }^{65} \mathrm{Cf}$. Section 3 of the 2008 report http://ec.europa.eu/europeaid/where/neighbourhood/ regional-cooperation/enpi-cross-border/index_en.htm
} 
relevance for the Arctic region. The formal agreement on Russian participation and co-financing achieved at the EU-Russia summit in November 2009 has allowed the programmes to become fully operational.

Kolarctic ${ }^{66}$ will receive nearly $€ 70.5$ million for the period up to 2013 , Norway having doubled, with $€ 14$ million, its contribution in respect of its preliminary commitment.

Karelia ${ }^{67}$ continues earlier cooperation under different programmes and aims at fostering economic development and improving the quality of life in the region. The programme for a total of nearly $€ 46.5$ million is financed for half of this sum by the EU, Finland and Russia contributing with an equal share to the other half.

While these "soft politics" relations are thriving, there does not appear to be much enthusiasm on the Russian side for supporting a more significant formalized role of the EU in Arctic cooperation. The September 2008 Basics of the State Policy of Russia in the Arctic to 2020 and beyond make clear the fundamental importance of the Arctic for Russia, but mention as a basic objective mutually advantageous bilateral and multilateral cooperation with the other circumpolar states. The partnership with the EU is only mentioned in relation to interparliamentary interaction.

It is therefore quite unlikely that the Arctic will be a prominent issue in the new EU-Russia Agreement, which is being negotiated since 2008.

\subsubsection{United States}

The US Arctic policy had an overhaul in January 2009 with the publication of the National Security Presidential Directive and Homeland Security Presidential Directive. As in other strategies, the Arctic Council is considered the privileged forum for cooperation. Furthermore, the text explicitly states that the US considers an "Arctic Treaty" as neither appropriate nor necessary. Cooperation on Arctic issues is seen predominantly in the framework of the UN and its specialized agencies, without excluding wider cooperation, particularly in the fields of environmental protection and research.

\footnotetext{
${ }^{66}$ http://www.kolarcticenpi.info/en (Cf. also Section 3.2.3 of the 2008 report for a detailed description)

${ }^{67}$ http://www.kareliaenpi.eu/en
} 
The Arctic has not been so far a visible issue in the bilateral relationship between the EU and the United States.

The only initiative of some relevance appears to be the Arctic TRANSFORM project, funded by the Commission's DG RELEX with the aim of identifying, on the basis of comparative policy analyses, transatlantic policy options for supporting adaptations in the marine Arctic in the fields of environmental governance, indigenous peoples, fisheries management, offshore hydrocarbons activities and shipping. The project was concluded with a high profile conference held in Brussels in March $2009^{68}$.

${ }^{68}$ http://arctic-transform.org/docs.html 


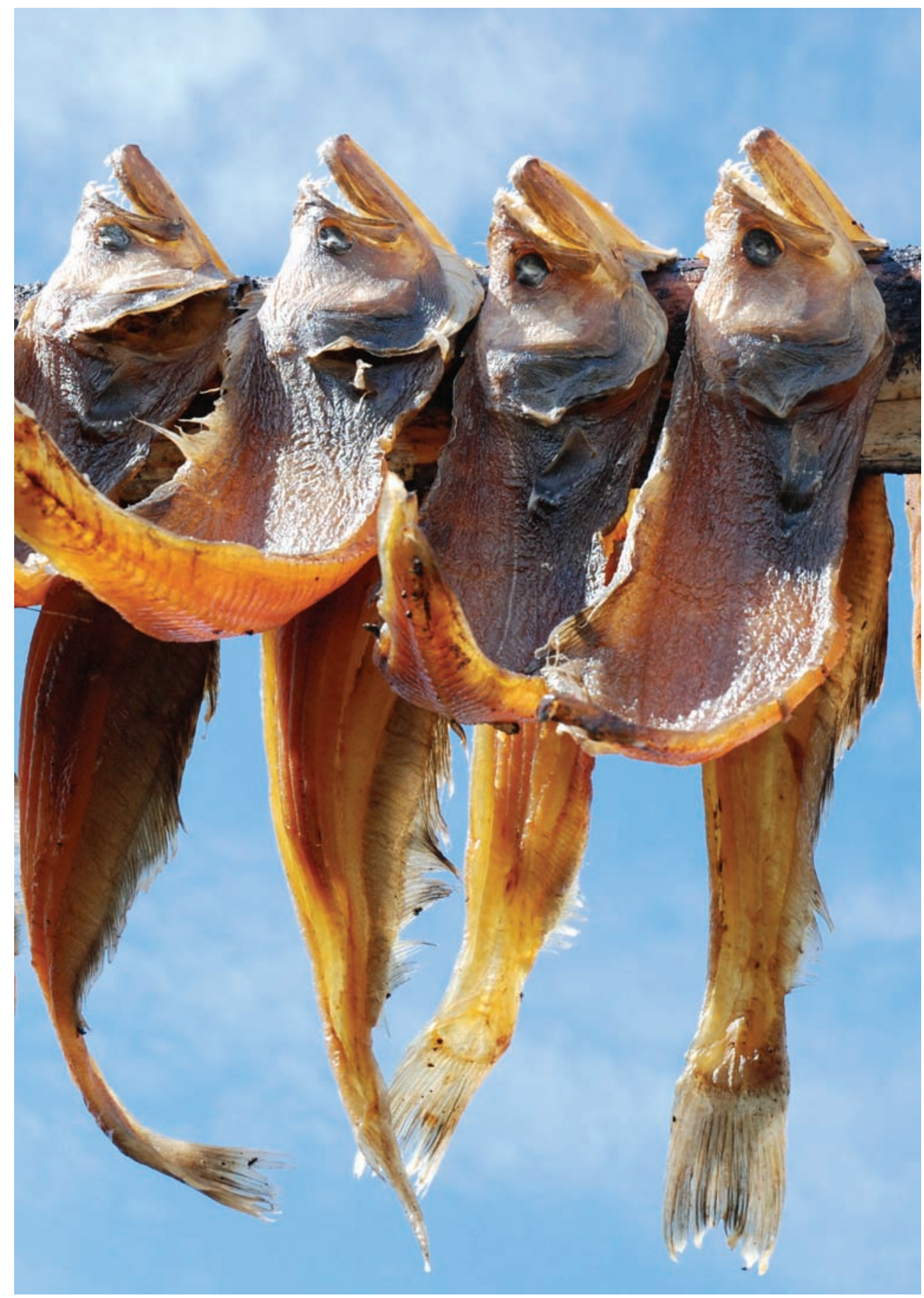




\section{A long and winding road - elements for interim assessment}

It is not an easy task for the EU to find its place in the Arctic context and direction for its approach to Arctic issues, particularly as it lacks a significant territorial basis in the Arctic region and a significant tradition of involvement in Arctic matters and in Arctic cooperation.

The actual and potential consequences of climate change, the same factors which, rather belatedly, have awoken the interest of the EU for the Arctic, have also worked in changing the nature of the international play in the region - from a relatively straightforward environmental cooperation to a more traditional and complex, though still "soft", power game.

The entrance of the EU into the game has, as a consequence, become more difficult than if it had been pursued in more innocent times. The fact that major players on the international scene, such as China and Japan, have also openly manifested their interest and others, such as India, may follow suit, has complicated the issue further. The EU has found itself, quite unexpectedly, in the situation of having to demonstrate that its interest in the Arctic is legitimate, and that a greater involvement in the Arctic can bring an added value recognized by Arctic states and other Arctic stakeholders.

The line the EU has taken is generally prudent and stepwise.

As it has already been underlined, the aim as declared by the Commission in its communication is to lead to an approach to Arctic matters as the first layer of an Arctic EU policy - structured and coordinated around main objectives of undisputable nature and importance, such as protection and preservation of the environment in unison with local populations, sustainable use of resources, contribution to enhanced multilateral governance based on the existing framework. The Council has given a general political blessing to this approach, if anything accentuating the will to remain within the existing 
framework and not to disturb the political balance in the Arctic. Hence, the quite visible effort to maintain a distance from the bolder political openings of the European Parliament in favour of a new overarching political framework for the Arctic.

Moreover, while the coupling of the concepts of new challenges and new opportunities has become common wisdom - and commonplace - whenever the present and evolving situation in the Arctic is mentioned, the EU has put the accent on cooperative or supportive action to address the challenges, rather than on seeking chances to take advantage of the opportunities. This is certainly the fruit of an evaluation of what was realistically possible, but it has also value as a consistent statement of intentions.

Activities undertaken by the EU in the period examined are consistent with this perspective. Research continues to be promoted as the privileged policy area for the EU/Arctic interaction. Consideration of Arctic aspects has also been particularly encouraged - and is developing - in the fields of environment and maritime affairs, especially maritime transport, where it concentrates on aspects of general importance such as pollution prevention and maritime safety. There is now, without any doubt, much greater awareness of the Arctic dimension in all relevant EU policies, which has resulted in some Arctic-specific initiatives, in greater financial support to actions in the Arctic, and in intensified attention to and participation in international fora dealing with Arctic issues.

Carefully tiptoeing into most issues, the EU has crashed into at least one, the ban on seal products. Heavily loaded with symbolism, the EU initiative has gained high visibility in the Arctic and attracted huge - arguably disproportionate - negative attention in the region, as a proof of the lack of consideration given by the EU to Arctic values and interests, and ultimately to Arctic populations.

While it would be unfair to judge EU action in the Arctic on the basis of this incident, it underlines an urgent need for the EU to establish ways by which information on its activities, actual and intended, could flow from its institutions to Arctic local communities, particularly indigenous peoples, and feed-back could be received and used to improve the nature and the consistency of EU action.

In conclusion, the developments described in this paper represent still an early stage of the process aiming at linking the EU and the Arctic, a process that - it should not be forgotten - has started less than two years ago, from 
low levels of concrete EU activities as well as a low level of interest by most Member States. It is also too early to foresee whether the process will lead to a fully fledged EU Arctic policy. What has so far been achieved internally is a more coordinated approach to Arctic issues - up to a point, and what has been undertaken externally is a cautious positioning in the framework of Arctic cooperation. This is hardly a "first layer" sufficiently strong and even to support building a policy. Similarly, talking of a EU Arctic strategy at this stage would be a misnomer.

A strategic decision on the next step may be taken after the progress report that the Commission will submit mid-2011, taking into account the forthcoming report of the European Parliament.

The general economic and political situation, particularly the evolution of the thinking in the Arctic Council, will obviously have a crucial influence in the development of the EU approach. The attitude of EU Arctic Member States but also of key Member States with a strong and growing interest in the Arctic region, such as France, Germany, Italy and the UK will also be a determining factor. In this context, the possible accession of Iceland is interesting, in that it could lead to strengthening the place of the EU in the Arctic or to strengthening the links between the inner core Arctic states.

Another element to be taken into consideration is the modification in the balance of powers within the EU brought about by the Lisbon Treaty, particularly the increased powers given to the European Parliament. The Parliament now co-decides with the Council on the EU budget and on legislation in most policy sectors, including many of importance for the Arctic, such as fisheries, tourism, structural funds. This gives the Parliament a strong bargaining hand, which will spill over into the sector of foreign policy. If in the main period covered by this paper Commission and Council could be considered the principal agenda-setters for the Arctic, in future the role of Parliament will be greater, and its pronouncements potentially far more influential.

If the EU wishes to become an accepted important player in the Arctic, it may have to balance its legitimate interest in the region and its political and economic weight in the international arena with the readiness to accept a place in Arctic cooperation which is not necessarily on the front row. What is already clear is that the EU, irrespective of whether it achieves full formal recognition in the exclusive Arctic club, would need in any case to develop a more coherent hierarchy of concrete priorities, widening the scope of its 
action to the whole Arctic region, and to pursue active cooperation with Arctic states notably in the framework of UNCLOS, IMO and relevant multilateral environmental agreements. 


\section{Sammenfatning}

En række EU-politikker og -aktiviteter påvirker Arktis, enten på grund af deres indhold eller deres territorielle målområde, som beskrevet i rapporten “The European Union and the Arctic - Policies and actions” fra 2008. Dette dokument er en opdatering til rapporten frem til juli 2010.

Kommissionens meddelelse „Den Europæiske Union og den arktiske region“ fra november 2008 samt „Rådets konklusioner om Arktis“ fra december 2009, som overordnet støtter meddelelsen i forhold til et styrket fokus på interne og eksterne politiske implikationer, anerkender behovet for en mere systematisk og struktureret tilgang til Arktis ud fra de tre hovedmålsætninger: at bevare Arktis i harmoni med dets befolkning, at fremme bæredygtig brug af ressourcer og at yde støtte til en øget multilateral forvaltning af Arktis - og identificere foranstaltninger, der skal efterstræbes inden for de relevante EU-politikker, for at disse målsætninger kan implementeres. En analyse af disse tekster viser, at EU opfatter bæredygtighed som det afgørende kriterium for sine foranstaltninger i Arktis. Den viser desuden, at EU agter at bidrage til en ordnet udvikling af den fælles indsats over for regionens udfordringer i tæt samarbejde med de arktiske stater og andre interessenter inden for de eksisterende samarbejdsrammer. I denne sammenhæng finder idéen om en traktat for Arktis, som oprindeligt blev præsenteret af EuropaParlamentet i 2008, ikke støtte.

De sektorer, hvor de Arktis-relevante foranstaltninger har gennemgået den største udvikling (i den to-årige periode, som dokumentet dækker), er fortsat forskning, miljø og maritime anliggender, særligt søtransport. Inden for disse sektorer er der blevet lanceret en række Arktis-specifikke initiativer, og deltagelsen i internationale aktiviteter er blevet øget. Der overvejes strategier til at puste nyt liv i Det Arktiske Vindue i den Nordlige Dimension. Ligeledes er opmærksomheden omkring og fokus på problemstillinger vedrørende Arktis i markant stigning på andre relevante politiske områder. 
Undtagelsen herfor er EU's foranstaltninger inspireret af dyrevelfærdshensyn - især forbuddet mod sælprodukter - som fortsat er i uoverensstemmelse med de arktiske befolkningers vision, særligt de oprindelige folk, og hæmmer deres økonomiske interesser. Det understreger behovet for, hvilket EU har erkendt, at fremme vedvarende gensidig dialog og udveksle oplysninger for at forhindre, at der opstår nye problemer af denne type.

Selvom en positiv indstilling hos lokalbefolkningen er et vigtigt element for, at EU's engagement i Arktis kan blive en succes, synes analysen af den bredere politiske kontekst at indikere, at vejen mod en fuldstændig accept af EU som aktør på den nuværende, komplekse politiske scene vedrørende Arktis stadig er op ad bakke. Næsten alle de arktiske stater har udarbejdet nationale strategier, hvori de har tilkendegivet klare synspunkter på, hvordan det arktiske samarbejde skal udvikle sig - med Arktisk Råd som det centrale, privilegerede forum - og særligt visse stater udviser en udpræget modvilje mod at åbne dette forum for andre deltagere. I denne sammenhæng består udfordringen for EU på dette stadium i yderligere at gøre sin tilstedeværelse gældende ved, på en målrettet og bæredygtig måde, at tilbyde sin erfaring og politiske og økonomiske vægt til støtte for at finde løsninger med international opbakning på de problemer, som hele Arktis udsættes for, fx tilpasning til klimaforandringer, luft- og havforurening og søtransportsikkerhed. Samtidig bør man tage del i den internationale indsats for at sikre, at de EUpolitikker og -foranstaltninger, der er relevante for Arktis, er mere konsistente og bedre prioriteret.

Den situationsrapport, som Kommissionen skal færdiggøre i midten af 2011, vil være en oplagt mulighed for at vurdere, hvorvidt, og i hvilken form, en fuldt udviklet EU-politik for Arktis er mulig og ønskelig, og til at udstikke den fremtidige kurs. 


\section{norden}

Nordic Council of Ministers

Ved Stranden 18

DK-1061 Copenhagen K

www.norden.org

The interest for the Arctic region has been intense in recent years, as demonstrated by intensified political debate on Arctic issues and increased national activity and multilateral cooperation in the region.

In this period the European Union has also paid increased attention to the Arctic region, expressed through the Commission's Arctic Communication (November 2008) and the Council's Conclusions (December 2009). The Arctic now appears as a recognized feature in EU policies and activities.

This paper by Ms. Adele Airoldi, commissioned by the Nordic Council of Ministers, describes and analyses the principal elements of the EU approach to Arctic issues as it has developed from July 2008 to July 2010, updating the report "The European Union and the Arctic - policies and actions" from 2008 . It reviews EU documents and pronouncements on Arctic issues, explores the development in the main EU policy sectors which impact the Arctic region and positions the EU in the wider Arctic political context through examining EU multilateral cooperation and bilateral relations.

It also aims at giving an input to the ongoing co-operation of the Nordic Council of Ministers with the EU on Arctic questions. 